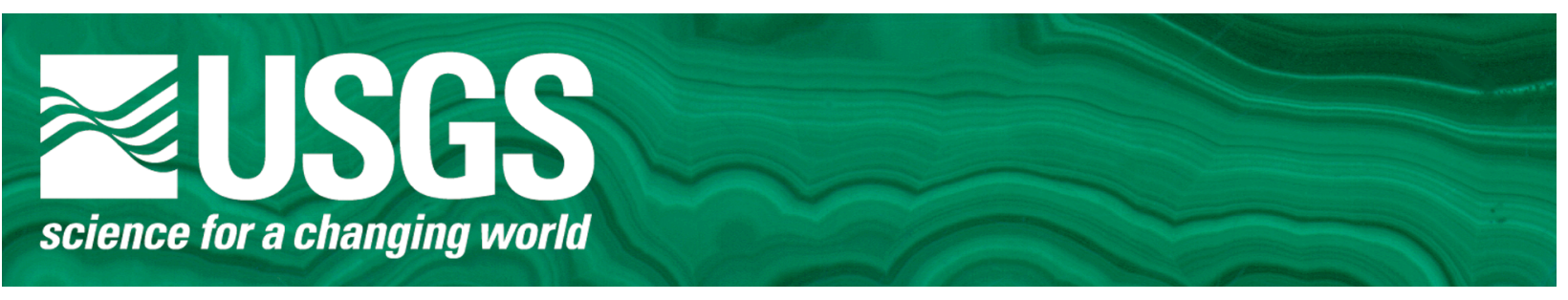

\title{
Sediment-Hosted Copper Deposits of the World: Deposit Models and Database
}

By Dennis P. Cox ${ }^{1}$, David A. Lindsey ${ }^{2}$ Donald A. Singer ${ }^{1}$, Barry C. Moring ${ }^{1}$, and Michael F. Diggles ${ }^{1}$

Including:

Descriptive Model of Sediment-Hosted Cu 30b.1 by Dennis P. Cox ${ }^{1}$

Grade and Tonnage Model of Sediment-Hosted Cu by Dennis P. Cox ${ }^{1}$ and Donald A. Singer ${ }^{1}$

Descriptive Model of Reduced-Facies Cu 30b.2 By Dennis P. Cox ${ }^{1}$

Grade and Tonnage Model of Reduced Facies Cu by Dennis P. Cox ${ }^{1}$ and Donald A. Singer ${ }^{1}$

Descriptive Model of Redbed Cu 30b.3, by David A. Lindsey ${ }^{2}$ and Dennis P. Cox ${ }^{1}$ Grade and Tonnage Model of Redbed Cu by Dennis P. Cox ${ }^{1}$ and Donald A. Singer ${ }^{1}$ Descriptive Model of Revett Cu 30b.4, by Dennis P. Cox ${ }^{1}$

Grade and Tonnage Model of Revett Cu by Dennis P. Cox ${ }^{1}$ and Donald A. Singer ${ }^{1}$

Open-File Report 03-107

Version 1.3

2003, revised 2007

Available online at http://pubs.usgs.gov/of/2003/of03-107/

Any use of trade, product or firm names is for descriptive purposes only and does not imply endorsement by the U.S. Government.

\section{U.S. DEPARTMENT OF THE INTERIOR U.S. GEOLOGICAL SURVEY}

${ }^{1} 345$ Middlefield Road, Menlo Park, CA 94025

2 Box 25046, Denver Federal Center, Denver, CO 80225 


\section{Introduction}

This publication contains four descriptive models and four grade-tonnage models for sediment hosted copper deposits. Descriptive models are useful in exploration planning and resource assessment because they enable the user to identify deposits in the field and to identify areas on geologic and geophysical maps where deposits could occur. Grade and tonnage models are used in resource assessment to predict the likelihood of different combinations of grades and tonnages that could occur in undiscovered deposits in a specific area. They are also useful in exploration in deciding what deposit types meet the economic objectives of the exploration company. The models in this report supersede the sediment-hosted copper models in USGS Bulletin 1693 (Cox, 1986, and Mosier and others, 1986) and are subdivided into a general type and three subtypes. The general model is useful in classifying deposits whose features are obscured by metamorphism or are otherwise poorly described, and for assessing regions in which the geologic environments are poorly understood. The three subtypes are based on differences in deposit form and environments of deposition. These differences are described under subtypes in the general model.

Deposit models are based on the descriptions of geologic environments and physical characteristics, and on metal grades and tonnages of many individual deposits. Data used in this study are presented in a database representing 785 deposits in nine continents. This database was derived partly from data published by Kirkham and others (1994) and from new information in recent publications. To facilitate the construction of grade and tonnage models, the information, presented by Kirkham in disaggregated form, was brought together to provide a single grade and a single tonnage for each deposit. Throughout the report individual deposits are defined as being more than 2,000 meters from the nearest adjacent deposit.

The deposit models are presented here as a PDF file. The database can be most conveniently read in FileMaker Pro. For those who do not have the FileMaker application, Microsoft-Excel, tab-delimited-ASCII and comma-separated-value files are included. The reader may be interested in a similar publication on porphyry copper deposits (Singer and others, 2005) also available online.

The Google Earth image is not intended to be viewed at the highest possible magnification because the resolution of the database is plus or minus two kilometers. At extreme zoom settings, the deposit locations may not coincide with the Google-Earth images of the mine workings.

The authors wish to thank William F. Cannon for his thoughtful review of this report.

\section{References}

Cox, D.P., 1986, Descriptive model of sediment-hosted copper in Cox, D.P., and Singer, D.A., eds., Mineral deposit models: U.S. Geological Survey Bulletin 1693, p. 205 [http://pubs.usgs.gov/bul/b1693/Md30b.pdf].

Kirkham, R.V, Carriere, J.J., Laramee, R.M., and Garson, D.F., 1994, Global distribution of sediment-hosted stratiform copper deposits and occurrences: Geological Survey of Canada Open File 2915b, 256 p.

Mosier, D.L., Singer, D.A., and Cox, D.P., 1986, Grade and tonnage model of sediment-hosted copper in Cox, D.P., and Singer, D.A., eds., Mineral deposit models: U.S. Geological Survey Bulletin 1693, p. 206. [http://pubs.usgs.gov/bul/b1693/Md30b.pdf]. 
Singer, Donald A., Berger, Vladimir I., and Moring, Barry C., 2005, Porphyry copper deposits of the world: database, map, and grade and tonnage models: U.S. Geological Survey OpenFile Report 2005-1060 [http://pubs.usgs.gov/of/2005/1060/]. 


\section{DESCRIPTIVE MODEL OF SEDIMENT-HOSTED COPPER}

MODEL 30b.1, Replaces Sediment-hosted Copper, 30b (Cox, 1986)

By Dennis P. Cox

\section{APPROXIMATE SYNONYMS}

Sandstone copper, shale-hosted copper, redbed $\mathrm{Cu}$, continental redbed, Kupferschiefer type, marine paralic type, reduced facies $\mathrm{Cu}$, Revett $\mathrm{Cu}$.

\section{DESCRIPTION}

Sediment-hosted copper deposits are stratabound, that is, they are restricted to a narrow range of layers within a sedimentary sequence but do not necessarily follow sedimentary bedding. They are epigenetic and diagenetic, that is, they are formed after the host sediment is deposited, but in most cases, prior to lithification of the host. They form independently of igneous processes.

\section{GENERAL REFERENCES}

Gustafson and Williams (1981), Lur'ye (1986), Kirkham (1989), Warren (1999, Chapter 8), Hitzman, Kirkham, Broughton, Thorson, and Selley, 2005.

\section{GEOLOGICAL ENVIRONMENT}

\section{Rock Types}

Host rocks are of two types: low-energy calcareous or dolomitic siltstones, shales and carbonate rocks of marine or lacustrine origin; and high-energy sandstones, arkoses and conglomerates of continental origin. Deposits of two distinct types are formed in these host rocks. Respectively they are described in Models 30b.2, reduced facies $\mathrm{Cu}$ and 30b.3, redbed $\mathrm{Cu}$ that follow this section.

\section{Textures}

Low energy rocks are thin-bedded to finely laminated and exhibit bacterial mat structures, stromatolites, fenestral structure, reef-building coral structures, mudcracks, crossbedding and other features of tidal environments. High-energy host rocks exhibit conglomerate- and sandstone-filled channels contain scour-and-fill, cross bedding, parallel lamination, mud rip-up clasts, and ripple marks. 


\section{Age Range}

No Archean deposits are known. Age distribution of deposits can best be described by the quantity of copper metal deposited during different time periods (fig. 1)

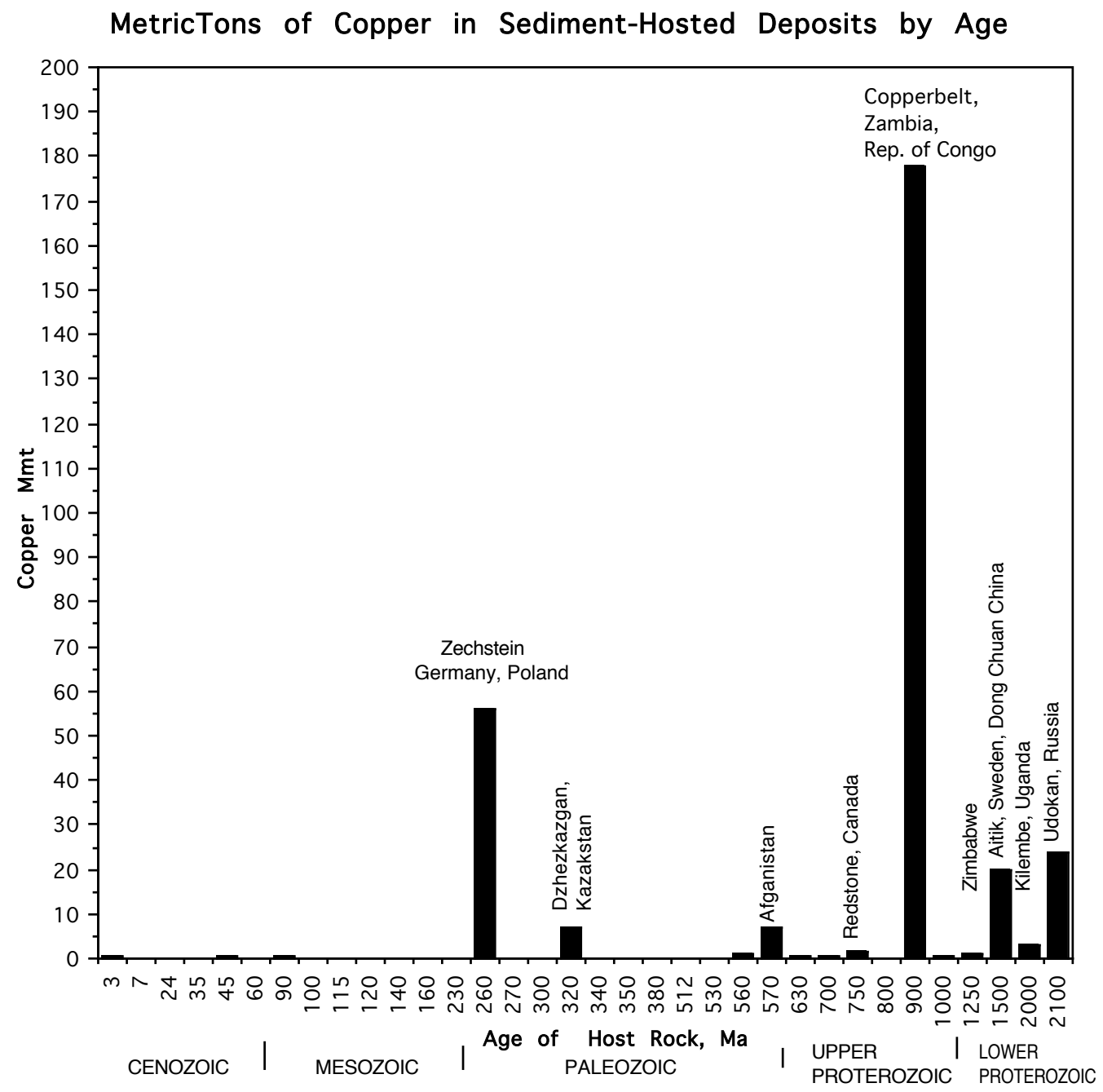

Figure 1. Distribution of copper metal (Million metric tons) in deposits of different ages.

The Upper Proterozoic rocks and, especially, Neoproterozoic rocks are the most productive. Permian rocks in Europe and Lower Carboniferous rocks in Central Asia are less important. Other small deposits are found throughout the Phanerozoic. 


\section{Depositional Environment}

Highly permeable sediments in epicontinental shallow-marine basins near the paleoequator. Sabkhas. High evaporation rate.

\section{Tectonic Setting(s)}

Favorable settings are intracontinental rifts, aulacogens, failed arms of triple junctions, and passive continental margins. Major graben and growth faults are commonly contemporaneous with mineralization.

\section{Associated Deposit Types}

Halite, sylvite, gypsum, anhydrite deposits occur in the same sedimentary sequences. Sandstone uranium, unconformity uranium, basalt copper, iron oxide copper gold deposits, and Kipushi $\mathrm{Cu}-\mathrm{Pb}-\mathrm{Zn}$ deposits can occur in the same districts.

\section{DEPOSIT DESCRIPTION}

Mineralogy All deposits contain one or more of the following minerals deposited in zones in this order: chalcocite and other $\mathrm{C}_{\mathrm{U}_{2}} \mathrm{~S}$ minerals, bornite, chalcopyrite, pyrite, and subordinate galena and sphalerite. Chalcocite forms near the oxidized source of copper; pyrite forms near the reduced rocks. Native copper occurs in deposits deficient in sulfide. Native silver is common. Some deposits in Zambia and Republic of Congo contain carrollite, Co-pyrite and Ge minerals.

Texture/Structure Minerals are finely disseminated, stratabound, locally stratiform. Framboidal or colloform pyrite is common. $\mathrm{Cu}$ minerals replace pyrite and cluster around carbonaceous clots or fragments.

Alteration Green, white, or gray rocks rich in Fe-calcite and chlorite result from reaction of reducing fluids with red beds. Oxidizing fluids produce albitic, hematite rocks depleted in base metals, calcium and potassium. Metamorphosed red beds may have a purple or violet color caused by finely disseminated hematite.

Ore Controls Reducing low pH environment such as marine black shale, fossil wood, algal mats are important as well as abundant biogenic sulfides and pyritic sediments. High permeability of footwall sediments is critical. Boundaries between hydrocarbon fluids or other reduced fluids and oxidized fluids in permeable sediments are common sites of ore deposition. 
Weathering Surface exposures may be completely leached. Secondary chalcocite enrichment is not present in many deposits because of low pyrite abundance and corresponding lack of acidic waters.

Geochemical Signature $\mathrm{Cu}, \mathrm{Ag}, \mathrm{Pb}, \mathrm{Zn}(\mathrm{Mo}, \mathrm{V}, \mathrm{U})(\mathrm{CO}, \mathrm{Ge})$. Au is low. Weak radioactivity is present in some deposits.

Environmental Considerations The zonal distribution of sulfide minerals must be considered in evaluating the environmental factors involved in mining sediment-hosted copper deposits. Chalcocite and bornite in the high-grade zone are fairly stable minerals in the oxidizing mine environment, and pyrite occurs only as trace amounts in this zone. In the low-grade zone, pyrite accompanies chalcopyrite and becomes increasingly abundant outward as copper grade decreases. This relationship should be used to guide mining plans where acid mine drainage caused by oxidizing pyrite must be avoided. Calcite is present in 20 deposits in the database and may be present in many more. The presence of calcite mitigates against the development of acid mine drainage.

The arsenic minerals tennantite, enargite, luzonite, and arsenopyrite are listed as minor or trace minerals in 10 deposits and occurrences in the database. Most of these 10 are important deposits that have received the attention of mineralogists. These are Mufulira, Democratic Republic of Congo; Mansfield, Germany; Graviisk, Russia, and Dzhezkazgan in Kazakstan. Five redbed occurrences in Permian and lower Triassic rocks in the Maritime Alps of France contain tennantite or enargite (Vinchon, 1984). These mineral occur with chalcopyrite as a late hydrothermal overprint on sedimentary-diagenetic bornite-chalcocite mineralization.

Arsenic, cadmium, mercury and nickel are listed in the descriptions of the geochemistry of Dezhkazgan and Graviisk. Mount Gunson, South Australia, contains anomalous arsenic (Knutson and others, 1983).

\section{GENETIC OVERVIEW}

Sediment-hosted copper deposits are formed by fluid mixing in permeable sedimentary and (more rarely) volcanic rocks. Two fluids are involved: an oxidized brine carrying copper as a chloride complex, and a reduced fluid, commonly formed in the presence of anaerobic sulfate-reducing bacteria. For a sediment-hosted copper deposit to form, four conditions are required:

1. There must be an oxidized source rock. This rock must be hematite stable and must contain ferromagnesian minerals or mafic rock fragments from which copper can be 
leached. In Zambia erosion of an early-formed porphyry copper deposit is thought to have contributed copper to the source rock (Wakefield, 1978). Typical source rocks are continental red sandstone, shale, conglomerate, and subaerial volcanic rocks. Marine volcanic rocks are unsuitable as source rocks because they have not degassed their volatile components. Contained reduced sulfur in marine volcanics precludes the formation of a hematite-stable environment.

Leaching of copper from the source rock at moderately low $\mathrm{pH}$ may be described by equation 1 .

$$
\mathrm{Cu}_{2} \mathrm{O}+6 \mathrm{Cl}^{-}+2 \mathrm{H}^{+}=2 \mathrm{CuCl}_{3}^{2-}+\mathrm{H}_{2} \mathrm{O}
$$

2. Following equation 1, there must be a source of brine to mobilize copper. Evaporites are commonly interbedded with red beds and act as brine sources, but any sedimentary environment in which evaporation exceeds rainfall will produce brines. Brines may also form by evaporation of sea water where connection with the open sea is restricted as in rift valleys. The brines are generally rich in sodium because other cations, potassium, calcium, and magnesium, are removed during formation of clays, sulfates, and carbonates. Davidson (1965) directed attention to the coincidence of evaporite deposits with Phanerozoic stratabound sediment-hosted copper deposits in many parts of the world and proposed that brine derived from evaporites was the transporting medium for copper and other metals.

3. There must be a source of reduced fluid to precipitate copper and form a deposit. The chemistry of brine formation, and copper mobilization and precipitation was described by Rose (1976). Reduced fluids can be derived from organic-rich shales and carbonate rocks, from pockets of liquid or gaseous hydrocarbons in the host sediments or from any sedimentary fluid in equilibrium with pyrite. In equation 2 copper-rich brine contacts organic material and produces native copper.

(2) $2 \mathrm{CuCl}_{3}{ }^{2-}+2 \mathrm{H}_{2} \mathrm{O}+\mathrm{C}=2 \mathrm{Cu}^{0}+1 \mathrm{CO}_{2}+4 \mathrm{H}^{+}+6 \mathrm{Cl}^{-}$

Note that $\mathrm{HCl}$ appears on the right of this equation and others below. This enables solution of carbonates and replacement of calcite cement by native copper.

Sulfide in the form of finely disseminated pyrite is commonly found in reduced host sediments. The amount of pyrite in typical black shale is insufficient to supply all of the sulfur in high-grade copper deposits. A more abundant source of sulfide is from reduction 
of sulfate by carbonaceous material, promoted by bacterial activity in the sediment (Sweeney and Binda, 1989) (equation 3).

$$
\mathrm{SO}_{4}{ }^{2--}+\mathrm{CH}_{4}=\mathrm{S}^{2-}+\mathrm{CO}_{2}+2 \mathrm{H}_{2} \mathrm{O}
$$

Reaction of chloride complex with sulfide produces chalcocite

$$
2 \mathrm{CuCl}_{3}^{2-}+\mathrm{S}^{2-}=\mathrm{Cu}_{2} \mathrm{~S}+6 \mathrm{Cl}^{-}
$$

Sulfate ion is commonly abundant in brines derived from evaporates and may accompany copper-rich oxidized solutions. Where this brine mixes with reduced fluids the following reaction describes the result.

$$
2 \mathrm{CuCl}_{3}{ }^{2-}+\mathrm{SO}_{4}{ }^{2-}+\mathrm{CH}_{4}=\mathrm{Cu}_{2} \mathrm{~S}+\mathrm{CO}_{2}+2 \mathrm{H}_{2} \mathrm{O}+6 \mathrm{Cl}^{-}
$$

Action of sulfate reducing bacteria is required to drive this reaction at near-surface temperatures.

4. There must be conditions favorable for fluid mixing. Haynes (1986) concluded that most sulfide ores are precipitated within 50 centimeters of the sediment-water interface because bacterial sulfate reduction below this depth is inhibited. Prelithification permeability in shale provides bedding-parallel sites for fluid mixing. Fluid pressures derived from sediment compaction is important factor in fluid mixing, and deposits are most commonly situated at basin margins where mixing is most likely to take place.

Faulting or folding may produce a hydraulic head that causes one fluid to invade the site of another. Disruption of sedimentary sequences by salt intrusion can also promote fluid mixing (see Jowett, 1986; Ruan and others, 1991; Avila-Salinas, 1990).

A permeable host rock or other open space must be present in which the fluids can mix. Intergranular space in fine-grained sediments prior to compaction and lithification is a common site for deposition. Solution cavities in carbonate rocks are less common depositional sites (MacKevett and others, 1997).

If any of these four conditions are not met, a deposit will not form, even in the most favorable rock environments. 


\section{Subtypes}

Three subtypes of sediment-hosted copper deposits with significant differences in tonnage and copper grade are recognized: reduced-facies $\mathrm{Cu}$ (56 deposits), redbed $\mathrm{Cu}$ (32 deposits), and Revett $\mathrm{Cu}$ (15 deposits). The three types differ in the strength and efficiency of the reductant at the site of deposition. In reduced-facies deposits, the reductant is a marine or lacustrine fine-grained sediment containing abundant organic matter. In redbed deposits, the reductant is more weakly distributed, represented by patches of organic debris in sandstone. In Revett $\mathrm{Cu}$ deposits, the reductant is broad and diffuse and in some Phanerozoic deposits can be shown to be gaseous or liquid hydrocarbon, or sulfide-rich sour gas.

Median tonnages are 2.0 Mmt for 35 redbed deposits, and $33 \mathrm{Mmt}$ for 58 reduced facies deposits, and $14 \mathrm{Mmt}$ for 11 Revett deposits. This difference between Redbed and reduced facies is significant at the one percent level, and between Redbed and Revett at the one percent level (such a difference could happen by chance less than one percent of the time).

Median copper grades are 1.6 percent for redbed and 2.3 percent for reduced facies deposits. This difference is significant the five percent level. Median copper grade for Revett $\mathrm{Cu}$ deposits 0.79 percent, and median silver grade is 31 grams per ton.

\section{THE DATABASE}

The database accompanying this report was compiled in 1997. It has not been revised for this version of the Open file Report. The database was based partly on a database of 950 deposits and occurrences of sediment-hosted stratiform copper deposits published by the Geological Survey of Canada (Kirkham and others, 1994). From this file, 133 deposits with data on tonnage and metal grade were extracted and reserve and production data were combined to provide a single tonnage-grade estimate for each deposit for use in statistical modeling. In cases where more than one tonnage-grade estimate was available, the one with the lowest cutoff grade was used. For purposes of tonnage and grade modeling, a deposit is defined as one or more separate ore bodies separated from its nearest neighbor by less than $2,000 \mathrm{~m}$. The median tonnage of the whole set of deposits is 10.6 million metric tons (Mmt) and the mean copper grade is $1.71 \mathrm{wt}$ percent. A silver grade is available for $32 \mathrm{of}$ these and the upper ten percent of deposits contains 31 grams per metric ton. Cobalt grade of the upper ten percent is $0.16 \mathrm{wt}$ percent based on data for 18 deposits. The distribution is log normal and tonnage and metal grades are independent. 


\section{Data Fields}

Deposit Name — The most recent name of the deposit is listed under "NameDeposit." Alternative names are listed under "Other Names" and names of other deposits within two kilometers of the main deposit are listed under "Includes."

Locations - Location by continent ("Cont"), Country, State, and Province are listed, as well as latitude and longitude in degrees, minutes and seconds and in decimal degrees. Negative latitudes are south of the equator; negative longitudes are east of the Greenwich Meridian.

Deposit ID — The deposits in the database were sorted first by latitude and then by longitude and given consecutive numbers listed as Deposit ID (see Table 1). This manner of sorting results in a broad east-west scatter of ID numbers that may cause difficulties for the user. If there is a missing number in a cluster of deposits, the user should search to the east or west to locate the deposit.

Tonnage and grade_- "OreMmt" refers to ore tonnage in millions of metric tons. Copper and cobalt grades are shown in percent and silver in parts per million (grams per metric ton).

Subtype-The sediment hosted copper model has been subdivided into redbed, reduced facies, and Revett subtypes (see discussion above). Deposits with insufficient data for classification or which differ in important ways form the major subtypes are labeled unclassified.

Age - The age of the host rock is shown in standard divisions of geologic time ("Age") and in millions of years where data is available ("Ma"). The name of the host stratigraphic unit is given when available.

Lithology — The rock types making up the host sedimentary bed ("HostRocks"), the overlying beds ("HangingWallBeds"), and underlying beds ("FootwallRocks") are listed where data is available.

Mineralogy — Ore and gangue minerals are isted in approximate order of abundance. Trace Minerals - Rare minerals of significance are shown separately. Comments - Associated rock types, structural controls of ore deposition are listed here as well as the presence in the ore of metals other than copper, cobalt, and silver. 


\section{REFERENCES}

Avila-Salinas, W., 1990, Origin of the copper ore at Corocoro, Bolivia in Fontbote, Amstutz, G. C., Cardozo, M., Cedillos, E., and Frutas, J., eds., Stratabound Ore Deposits of the Andes: Berlin-Heidelberg, Springer Verlag, p. 659-670.

Davidson, C.F., 1965, A possible mode of origin of strata-bound copper ores: Economic Geology, 60, p. 942-954. v.

Haynes, D.W., 1986a, Stratiform copper deposits hosted by low-energy sediments: I.

Timing of sulfide precipitation—an hypothesis: Economic Geology, v.81, p. 250-265.

Hitzman, Murray, Kirkham, Rodney, Broughton, David, Thorson, Jon, and Selley, David, 2005, The sediment-hosted stratiform copper ore system: Economic Geology $100^{\text {th }}$ Anniversary Volume, p. 609-642.

Jowett, E.C., 1986, Genesis of Kupferschiefer Cu-Ag deposits by convective flow of Rotliegende brines during Triassic rifting: Economic Geology, v.8, p. 1723-1837.

Kirkham, R.V, Carriere, J.J., Laramee, R.M., and Garson, D.F., 1994, Global distribution of sediment-hosted stratiform copper deposits and occurrences: Geological Survey of Canada Open File 2915b, 256 p.

Knutson, Janice, Donnelly, T.H., and Tonkin, D.G., 1983, Geochemical constraints on the genesis of copper mineralization in the Mount Gunson area, South Australia: Economic Geology v. 78, p. 250-274.

MacKevett, E.M., Jr., Cox, D.P., Potter R.W., II, and Silberman, M.L., 1997, Kennecotttype deposits, Wrangell Mountains, Alaska: High-grade copper deposition near a limestone-basalt contact in Goldfarb, R.J. and Miller, L.D., eds., Mineral deposits of Alaska: Economic Geology Monograph 9, p. 66-89.

Ruan Huichu, Hua Renmin, and Cox, D.P., 1991, Copper deposition in deformed strata adjacent to a salt diapir, Dongchuan Area,Yunnan Province, China: Economic Geology v.86, p.1539-1545.

Rose, A.W., 1976. The effect of cuprous chloride complexes in the origin of red-bed copper and related deposits, Economic Geology, v.71, p. 1036-1048.

Sweeney, M.A. and Binda, P.L., 1989, The role of diagenesis in the formation of the Konkola Cu-Co orebody of the Zambian Copperbelt in Boyle, R.W., Brown, A.C., Jefferson, C.W., Jowett, E.C., and Kirkham, R.V. eds., Sediment-hosted Stratiform Copper Deposits: Geological Association of Canada Special Paper 36. p. 499-518. 
Vinchon, C., 1984, Sédimentogénese et métallogénese du Permien du Dôme du Barrot (Alpes Maritimes France): Documents du B.R.G.M. No. 70, 444 p.

Wakefield, J., 1978, Samba: a deformed porphyry-type copper deposit in the basement of the Zambian Copperbelt: Institute of Mining and Metallurgy, v. 87, B43-B52.

Warren, John, 1999, Evaporites, their evolution and economics: Blackwell Science, Oxford, 438 p. (see Chapter 8). 
TABLE 1

\begin{tabular}{|c|c|c|c|}
\hline COUNTRYCODE & COUNTRY & COUNTRYCODE & COUNTRY \\
\hline $\mathrm{AFGH}$ & Afghanistan & $\mathrm{MXCO}$ & Mexico \\
\hline AGTN & Argentina & NAMB & Namibia \\
\hline ALGR & Algeria & NGRA & Nigeria \\
\hline ANGL & Angola & NRWY & Norway \\
\hline AUNT & Australia & PERU & Peru \\
\hline AUSA & Australia & PKTH & Pakistan \\
\hline AUVT & Australia & PLND & Poland \\
\hline BLGM & Belgium & PLPN & Philippines \\
\hline BLVA & Bolivia & RUSA & Russia \\
\hline BOTS & Botswana & SAAR & Saudi Arabia \\
\hline BRZL & Brazil & SAFR & South Africa \\
\hline CILE & Chile & SLOV & Slovak Republic \\
\hline CINA & China & SLVN & Slovenia \\
\hline CLBA & Colombia & SPAN & Spain \\
\hline CNAL & Canada Alberta & SWDN & Sweden \\
\hline CNBC & Canada Br. Columbia & SWIS & Switzerland \\
\hline CNGO & Congo Brazzaville & TADZ & Tajikistan \\
\hline CNNB & Canada New Brunswick & THLD & Thailand \\
\hline CNNF & Canada Newfoundland & UGND & Uganda \\
\hline CNNS & Canada Nova Scotia & UKEN & England \\
\hline CNNT & Canada Northwest Terr. & UKIR & Ireland \\
\hline CNON & Canada Ontario & UKRA & Ukraine \\
\hline CNPE & Canada Prince Edward I & UKSC & Scotland \\
\hline CNQU & Canada Quebec & USAZ & United States Arizona \\
\hline CNSA & Canada Saskatchewan & USCO & United States Colorado \\
\hline CNWT & Canada Northwest Terr. & USID & United States Idaho \\
\hline CNYT & Canada Yukon Terr. & USKS & United States Kansas \\
\hline CZEC & Czech Republic & USMI & United States Michigan \\
\hline EGPT & Egypt & USMO & United States Missouri \\
\hline FRNC & France & USMT & United States Montana \\
\hline GABN & Gabon & USNJ & United States New Jersey \\
\hline GRLD & Greenland & USNM & United States New Mexico \\
\hline GRMY & Germany & USOK & United States Oklahoma \\
\hline HUNG & Hungary & USPA & United States Pennsylvania \\
\hline INDA & India & USSD & United States South Dakota \\
\hline IRAN & Iran & USTN & United States Tennessee \\
\hline ISRL & Israel & USTX & United States Texas \\
\hline ITLY & Italy & USUT & United States Utah \\
\hline JMCA & Jamaica & USVA & United States Virginia \\
\hline JRDN & Jordan & USWY & United States Wyoming \\
\hline KAZN & Kazakhstan & UZBN & Uzbekistan \\
\hline KYRZ & Kyrgyzstan & VNZL & Venezuela \\
\hline LAOS & Laos & YUGO & Yugoslavia \\
\hline MALI & Mali & ZIMB & Zimbabwe \\
\hline MNGL & Mongolia & ZIRE & Democratic Republic of Congo \\
\hline MRCO & Morocco & ZMBA & Zambia \\
\hline
\end{tabular}


Model 30b.1

GRADE AND TONNAGE MODEL OF SEDIMENT-HOSTED Cu

By Dennis P. Cox and Donald A. Singer

(Replaces Model 30b of Mosier and others (1986)

COMMENTS: A deposit is defined as one or more separate orebodies separated from its nearest neighbor by more than $2,000 \mathrm{~m}$.

\section{DEPOSITS}

Name

Agoujgal

Aitik

Al Mehdadah

Alaska

Alderly Edge

Avaroa

Aynak

Bagacay

Ballyvergin

Barda González

Big Indian

Blinman

Boleo

Burra

Bushman Group

Bwana Mkubwa

Cachoeiras de Binga

Caleta Coloso

Camaquã District

Canfield Dome

Cashin

Cerro dos Martíns

Cerro Granito

Chacarilla

Chambishi

Chibuluma South

Chibuluma-Chibuluma West

Chifupu

Chimiwungo-Lumwana

Chingola

Coates Lake

Corocoro

Creta

Darband

Dorchester

Dzhezkazgan

Esmeralda

Etoile

Fenan

FengShan

Fitula

Country
MRCO
SWDN
SAAR
ZIMB
UKEN
BLVA
AFGH
PLPN
UKIR
AGTN
USUT
AUSA
MXCO
AUSA
BOTS
ZMBA
ANGL
CILE
BRZL
CNDA
USCO
BRZL
AGTN
BLVA
ZMBA
ZMBA
ZMBA
ZMBA
ZMBA
ZMBA
CNNT
BLVA
USOK
AFGH
CNNS
KAZN
BLVA
ZIRE
JRDN
CINA
ZMBA

Name

Fungurume

Itawa

Jabal Murryyi

Jardin

Jay

JF

Juaramento

June Creek

Kabolela

Kakanda

Kalengwa

Kamatanda

Kambove

Kamfundwa

Kanmantoo

Kansanshi

Kasaria

Kilembe

Kimbwe

Kinsenda

Klein Aub

Kolwezi

Kona Dolomite

Konkola-Kirila Bombwe

Konrad

Ladderbjerg

LaoXue

Las Vigas

Lisbon Valley

Lochaber Lake

Luanshya

Luansobe

Lubin

Lubwe

Luishia

Lukuni

Lupato

Mallow

Malundwe-Lumwana

Mangula

Mangum
Country

ZIRE

ZMBA

SAAR

CILE

CNNT

USMT

AGTN

CNNT

ZIRE

ZIRE

ZMBA

ZIRE

ZIRE

ZIRE

AUSA

ZMBA

ZMBA

UGND

ZIRE

ZIRE

NAMB

ZIRE

USMI

ZMBA

PLND

GRLD

CINA

MXCO

USUT

CNNS

ZMBA

ZMBA

PLND

ZMBA

ZIRE

ZIRE

ZIRE

UKIR

ZMBA

ZIMB

USOK 
Model 30b.1--Con.

Name
Mansfeld
Marsberg
Martín Bronce
Matsitama
Menda Mendipe
Mimbula
Mindola-Nkana N-S
Missoula National
Mokambo
Mount Gunson
Mufulira
Mufumbwe
Mutoshi
Mwambashi
Mwerkera
Nacimiento
Nchanga
Ngwako Pan
Niagara
Nkana North Limb
Norah
Oamites
Pedra Verde
Pitanda
Pitanda South
Presque Isle
Repparfjord

Country
GRMY
GRMY
AGTN
BOTS
ZIRE
ZMBA
ZMBA
USID
ZMBA
AUSA
ZMBA
ZMBA
ZIRE
ZMBA
ZMBA
USNM
ZMBA
BOTS
USID
ZMBA
ZIMB
NAMB
BRZL
ZMBA
ZMBA
USMI
NRWY

Name
Richelsdorf
Rock Creek
Rubjerg Knude
San Bartolo
San Romeleo
Serra do Diamante
Sesa
Shackleton
ShiShan
ShiZhiShan
Scholle
Silverside
Snowstorm
Spar Lake
Stauber
Talat n Ouamane
TangDan
Tansrift
Tenke
Timna
Turco
Udokan
Uyuni
Vermillion River
White Pine
Witvlei
YinMin

Country

GRMY

USMT

GRLD

CILE

AGTN

BRZL

ZIRE

ZIMB

CINA

CINA

USNM

ZIMB

USID

USMT

USNM

MRCO

CINA

MRCO

ZIRE

ISRL

BLVA

RUSA

BLVA

USMT

USMI

NAMB

CINA 


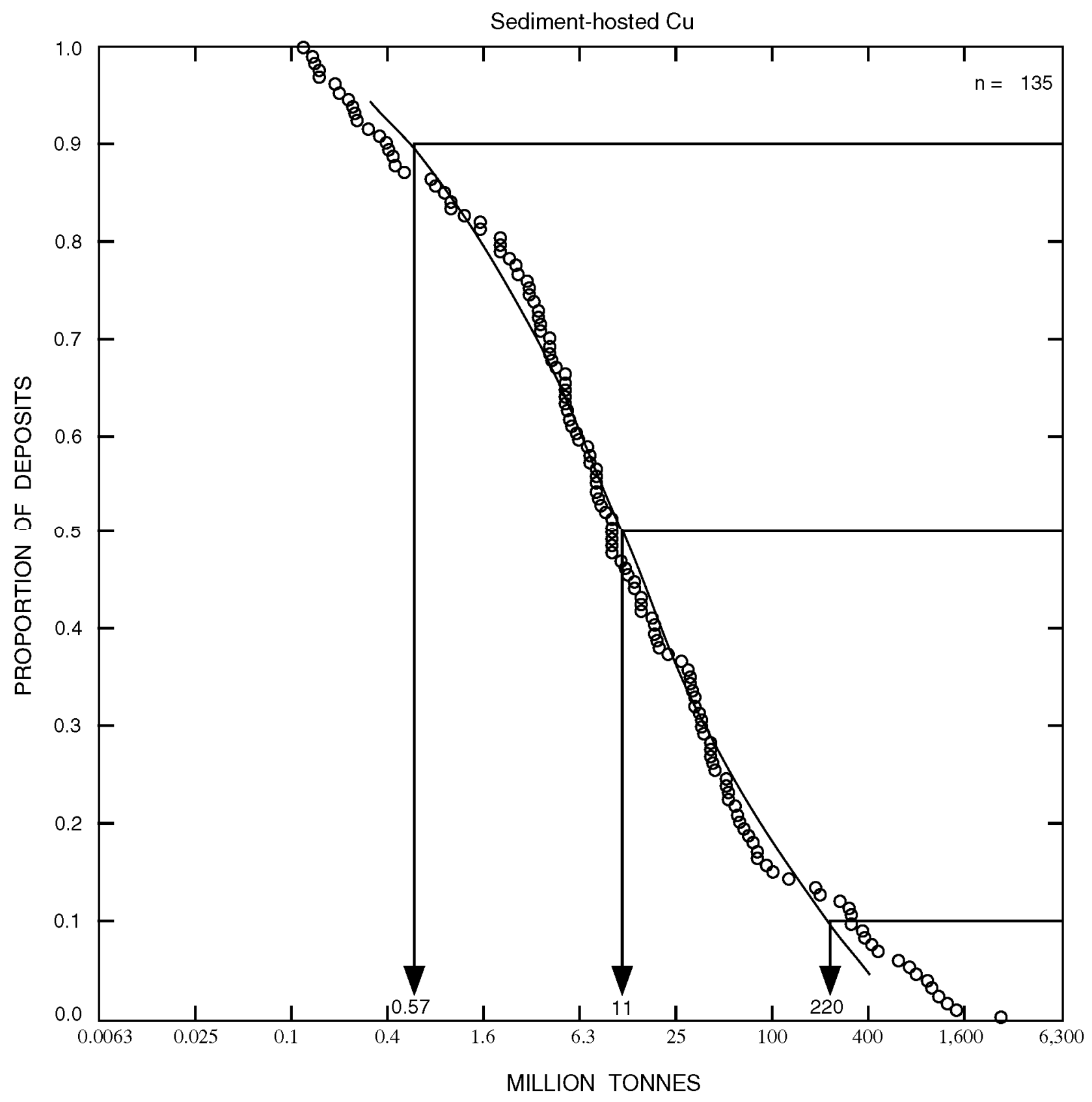

Figure 1. Tonages of sediment-hosted $\mathrm{Cu}$ deposits 


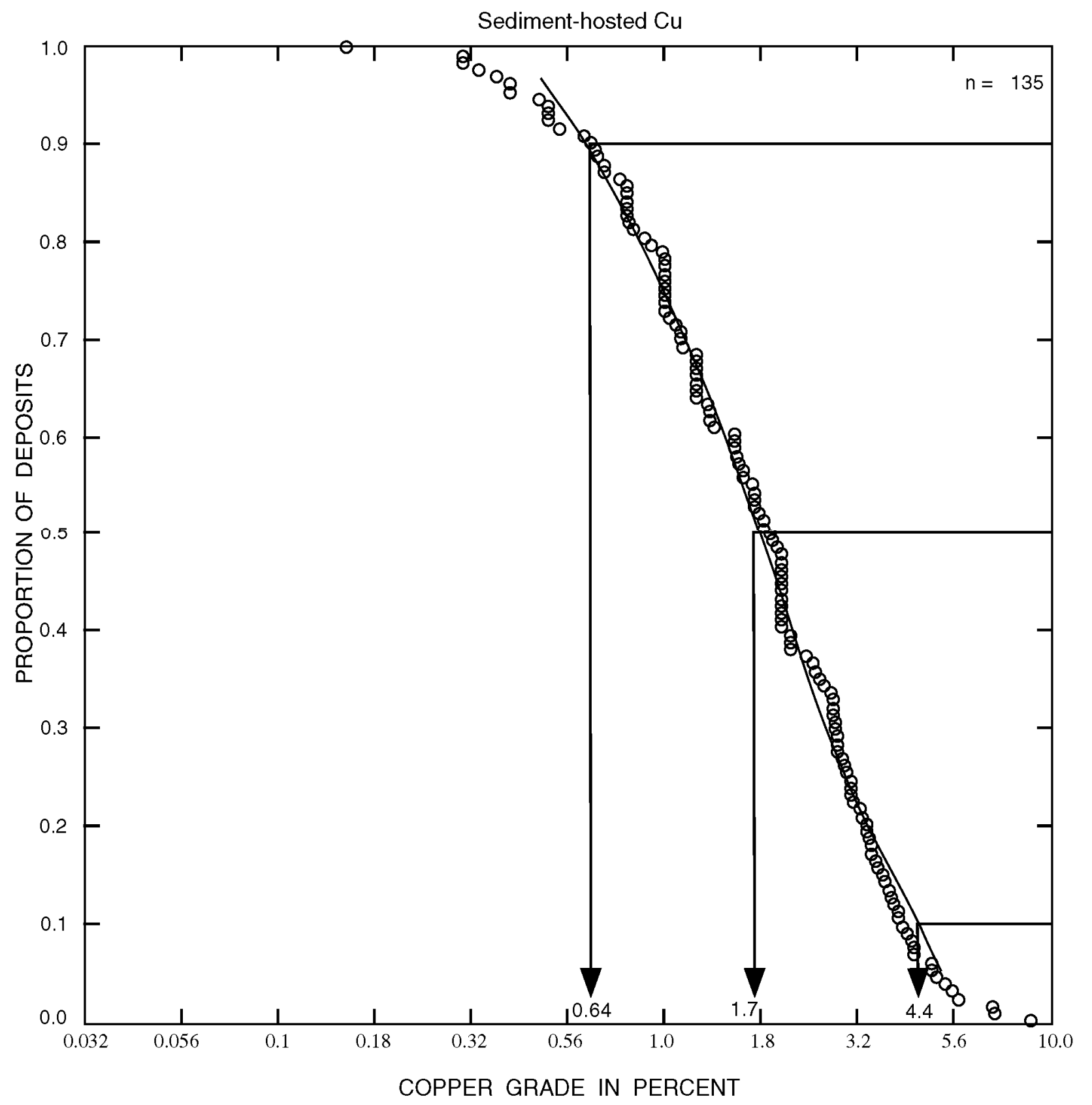

Figure 2. Copper grades of sediment-hosted $\mathrm{Cu}$ deposits. 


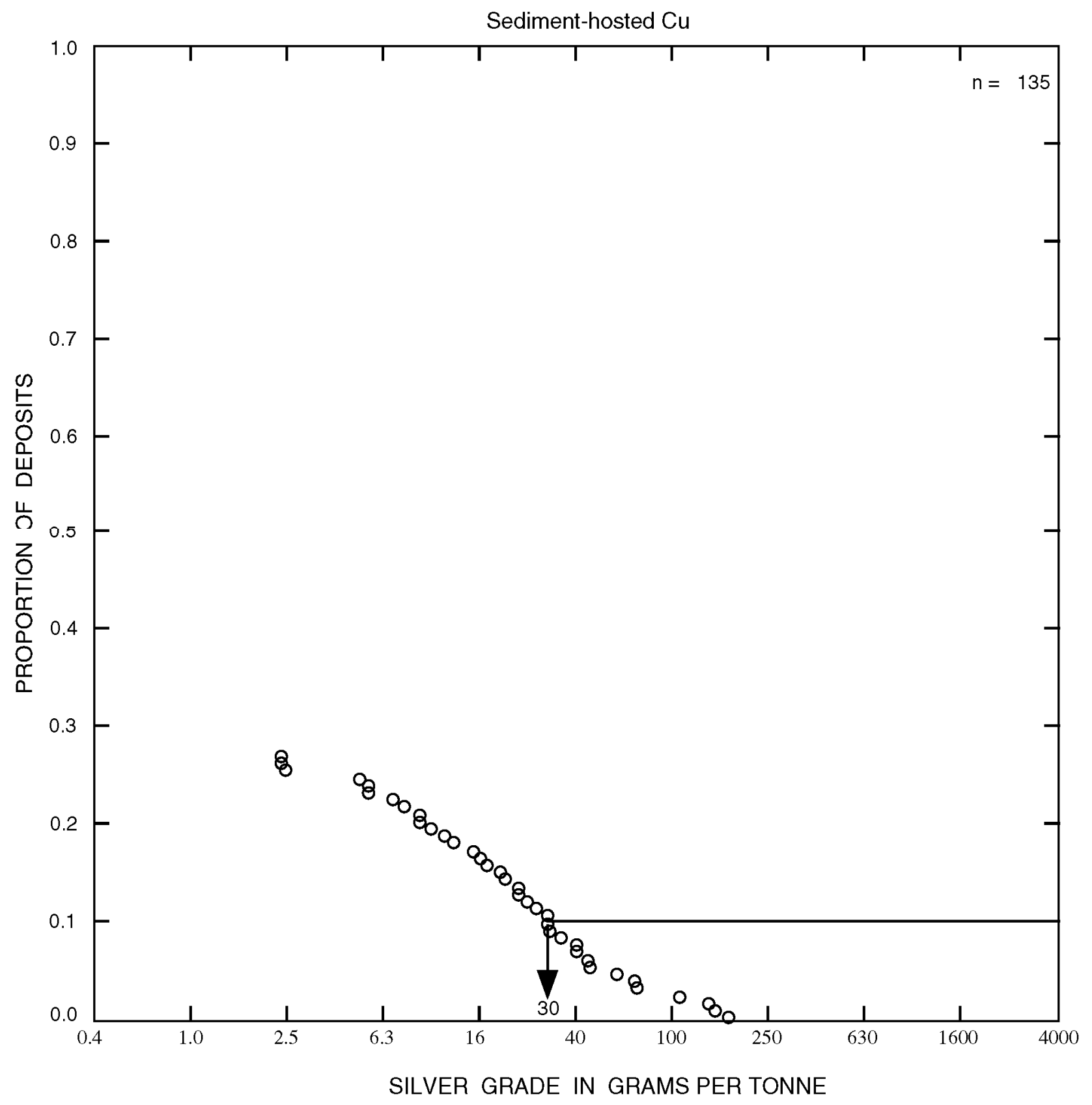

Figure 3. Silver grades of sediment-hosted $\mathrm{Cu}$ deposits. 


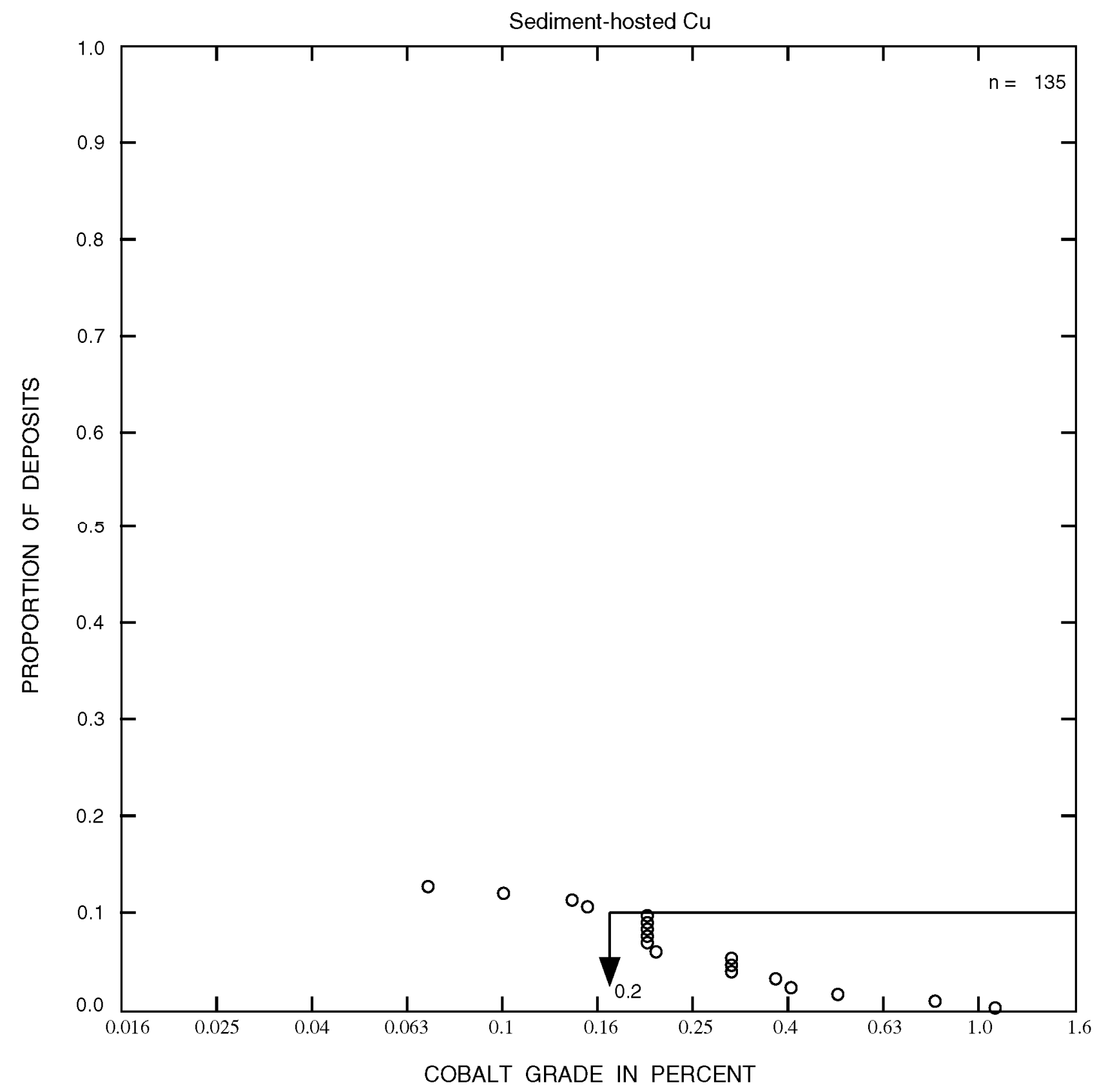

Figure 4. Cobalt grades of sediment-hosted $\mathrm{Cu}$ deposits. 


\title{
DESCRIPTIVE MODEL OF REDUCED-FACIES SUBTYPE
}

MODEL 30b.2, (Replaces Sediment-hosted Copper, 30b, Cox, 1986)

By Dennis P. Cox

\begin{abstract}
APPROXIMATE SYNONYMS Copper-shale (Lindsey, 1982); stratiform copper hosted by low-energy sediments (Haynes, 1986a); marine paralic (Kirkham, 1994); Kupferschiefer type (Kirkham, 1989); Central African type.

DESCRIPTION Stratabound, disseminated copper sulfide deposits in reduced-facies sedimentary rocks that overlie, or are interbedded with, red-bed sequences or subaerial basalt flows. Copper is mobilized by oxidized brines in redbeds; sulfide-bearing fluids are derived from reduction of sulfate in marine or lacustrine sediments. Subsequent tectonism causes fluid mixing and sulfide deposition.
\end{abstract}

GENERAL REFERENCES Gustafson and Williams (1981), Lur'ye (1986), Kirkham (1989), Sweeney and others (1991).

\section{GEOLOGICAL ENVIRONMENT}

Rock Types Host rocks are reduced facies marine or lacustrine rocks such as green, black, or gray shale, siltstone, thinly laminated tidal facies, or reefoid carbonate rocks, and dolomitic shales. Fine-grained clastic rocks and carbonates host 69 percent of deposits and occurrences ( Table 1). Organic carbon and finely disseminated pyrite are common constituents. Host rocks for 16 percent of the occurrences are described as carbonaceous, bituminous, algal or stromatolitic.

\begin{tabular}{|l|c|l|c|l|c|}
\hline Deposit Type & $\begin{array}{l}\text { Number of } \\
\text { deposits and } \\
\text { occurrences }\end{array}$ & $\begin{array}{l}\text { Sandstone, } \\
\text { quartzite, } \\
\text { arkose, } \\
\text { conglomerate }\end{array}$ & $\begin{array}{l}\text { Siltstone, } \\
\text { shale, clay } \\
\text { mudstone, }\end{array}$ & $\begin{array}{l}\text { Limestone, } \\
\text { dolomite, } \\
\text { marl }\end{array}$ & $\begin{array}{l}\text { Schist, } \\
\text { phyllite, } \\
\text { amphibolite, } \\
\text { marble }\end{array}$ \\
\hline Reduced facies & 100 & 29 & 41 & 28 & 2 \\
\hline Redbed & 155 & 85 & 12 & 2.5 & $<1$ \\
\hline Revett & 31 & 77 & 22 & 0 & 0 \\
\hline Unclassified & 102 & 30 & 20 & 25 & 25 \\
\hline
\end{tabular}

Table 1. Host rocks of mineralization for individual occurrences by type expressed in percent of occurrences having a host rock description). 
These host rocks overlie, or are interbedded with redbed sequences containing red to brown or purple hematite-bearing sandstones siltstones and conglomerate of continental deltaic, fluviatile, or aeolian origin (tables 2 and 3). Mafic dikes and sills formed during rifting are present locally. Thick, subaerial basalt flows are important as sources of copper in a few deposits. Evaporite beds are important as a source of brine for many deposits (tables 2 and 3). In metamorphosed sequences, missing intervals in the stratigraphic section are evidence for original evaporites.

According to the Sediment-Hosted Copper database, reduced facies deposits are underlain by a variety of rock types dominated by sandstone and conglomerate (table 2).

\begin{tabular}{|l|c|c|c|l|c|c|}
\hline $\begin{array}{l}\text { Deposit } \\
\text { subtype }\end{array}$ & $\begin{array}{l}\text { Sandstone, } \\
\text { quartzite, } \\
\text { arkose, }\end{array}$ & $\begin{array}{l}\text { Conglom- } \\
\text { erate }\end{array}$ & $\begin{array}{l}\text { Siltstone, } \\
\text { shale, clay } \\
\text { mudstone, }\end{array}$ & $\begin{array}{l}\text { Limestone, } \\
\text { dolomite, } \\
\text { marl }\end{array}$ & $\begin{array}{l}\text { Evapor- } \\
\text { ite }\end{array}$ & $\begin{array}{l}\text { Mafic } \\
\text { lava }\end{array}$ \\
\hline $\begin{array}{l}\text { Reduced } \\
\text { facies }\end{array}$ & 49 & 12 & 11 & 15 & 8 & 4 \\
\hline Redbed & 39 & 26 & 13 & 8 & 0 & 13 \\
\hline
\end{tabular}

Table 2. Rocks underlying mineralization for individual occurrences by type expressed in percent of occurrences having a description of the underlying rock (47 reduced facies and 26 redbed).

Reduced facies deposits in the database are most commonly overlain by carbonates, but sandstone, shale and evaporates are locally important (table 3 ).

\begin{tabular}{|l|l|l|l|l|}
\hline $\begin{array}{l}\text { Deposit } \\
\text { subtype }\end{array}$ & $\begin{array}{l}\text { Sandstone, } \\
\text { quartzite, } \\
\text { arkose, } \\
\text { conglomerate }\end{array}$ & $\begin{array}{l}\text { Siltstone, } \\
\text { shale, clay } \\
\text { mudstone, }\end{array}$ & $\begin{array}{l}\text { Limestone, } \\
\text { dolomite, } \\
\text { marl }\end{array}$ & $\begin{array}{l}\text { Evaporite, } \\
\text { gypsum }\end{array}$ \\
\hline Reduced facies & 27 & 20 & 42 & 10 \\
\hline
\end{tabular}

Table 3. Rocks overlying mineralization for individual occurrences by type expressed in percent of 40 occurrences having a description of the overlying rock.

Textures Reduced facies rocks are thin-bedded to finely laminated and exhibit bacterial mat structures, stromatolites, fenestral structure, reef-building coral structures, mudcracks, crossbedding and other features of tidal environments.

Age Range Deposits are restricted to periods of Earth history in which the atmosphere was oxygenated. Udokan in Russia is Lower Proterozoic (Bolodin and others, 1994). Most deposits favor Middle and Late Proterozoic rocks worldwide. Permian rocks host major deposits in Germany and Poland, Permian and early Mesozoic rocks in Eastern Europe and USA. All ages from Lower Proterozoic are possible. The figure below shows 
the estimated amount of copper deposited during Earth history. The numbers in the horizontal scale represent ages of the major deposits shown in the histogram.

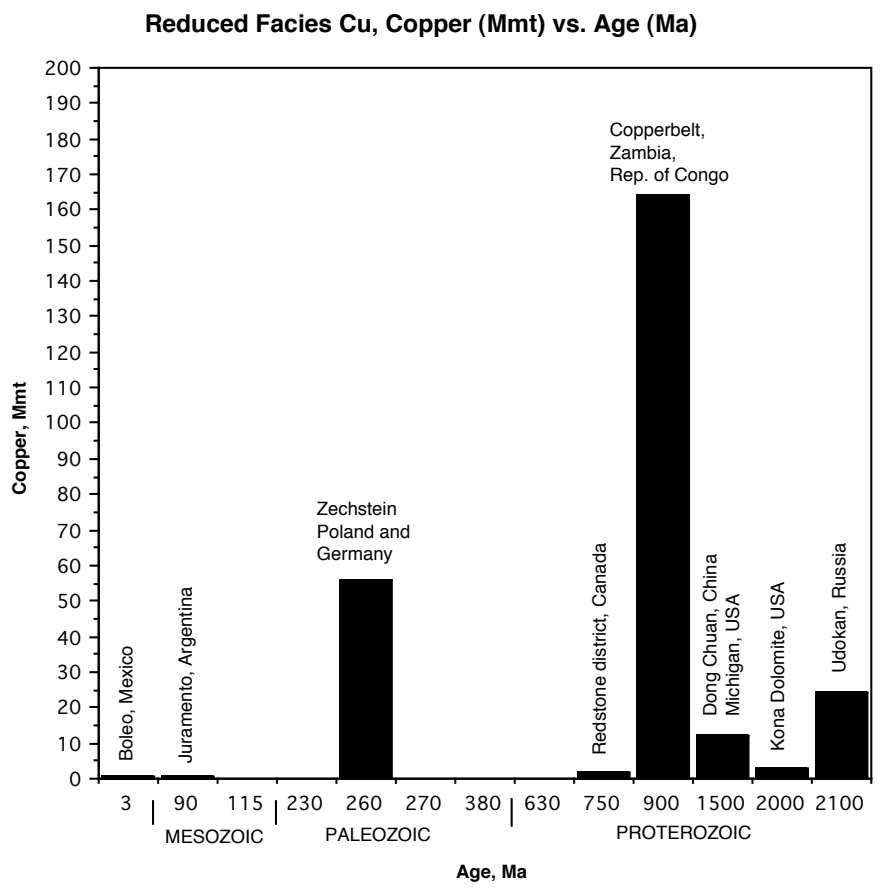

Depositional Environment Deposits form in continental clastic sedimentary basins succeeded by epicontinental shallow-marine or lacustrine basin within $30^{\circ}$ of the paleoequator. Sabkhas, evaporites, or other sources of brines are important. Most deposits form during transgression of reduced marine sediments over redbed deposits (Brown and Chartrand, 1986). In the terminology of sequence stratigraphy, deposits are in condensed stratigraphic sections resulting from maximum flooding (Ruffell and others, 1998). In Zambia ores are found along the paleoshoreline (Fleischer and others, 1976). Deposits are zoned from chalcocite to bornite to chalcopyrite to pyrite away from the shoreline toward anoxic deep water. According to Haynes (1986a), most deposits are formed less than 50 $\mathrm{cm}$ below the sediment water interface because bacterial reduction of sulfate is inhibited below that depth. Deposits commonly have a mineral zonation from chalcocite to bornite to chalcopyrite to pyrite upward from the contact of host rocks with underlying redbeds. 
The occurrence in Zambia of sulfide grains in foreset beds and in troughs of ripple marks suggests that some sulfide precipitation may take place above the water-sediment surface (Fleischer and others, 1976). Garlick (1989) presented evidence from the Copperbelt for transport of copper by surficial brines flowing across sabkha deposits and into anoxic marine waters trapped behind algal reefs. The high density of the brines would cause rapid mixing with bottom water and precipitation of copper sulfides. These sulfides plus detrital quartz and clays would descend to the sea floor and form the ore beds.

Many of the most important sediment-hosted copper deposits were formed during the Neoproterozoic when most of the world's continental masses were joined in the Rodinia supercontinent. The presence of diamictites with striated clasts and scoured basal pavements suggest that two or more periods of continental glaciation occurred in the Neoproterozoic. These diamictite layers are overlain by thick deposits of carbonate rocks. Sediment-hosted copper deposits, where present, are below the diamictite layers, and were apparently formed during warm periods preceding glaciation. Thus Neoproterozoic sequences in which diamictites occur near the base of the section are probably not permissive for sediment-hosted copper deposits.

Tectonic Setting(s) An intracontinental rift or aulacogen with restricted marine circulation, succeeded by widespread euxinic marine deposits is the ideal setting for these deposits. Salt diapirism, major growth faults, thinning of sedimentary units, and unconformities may focus fluid flow and influence localization of deposits.

Lefebvre (1989) noted the importance of normal faulting in southern Shaba, Republic of Congo. He believes that hydrothermal solutions emanating from these faults were a major source of copper and cobalt in the sediments.

Associated Deposit Types Halite, sylvite, gypsum, and anhydrite deposits and redbed $\mathrm{Cu}$ deposits are formed contemporaneously. Unconformity-related uranium, and Kipushi $\mathrm{Cu}-\mathrm{Pb}-\mathrm{Zn}$ occur in overlying carbonate rocks in Southern Africa. Deposits of lead and zinc at Lubin in Poland are similar to sandstone lead deposits, but should be considered as distal parts of the reduced facies model. 


\section{DEPOSIT DESCRIPTION}

Mineralogy Chalcocite and other $\mathrm{Cu}_{2} \mathrm{~S}-\mathrm{CuS}$ minerals + bornite are the diagnostic minerals. Deposits may be zoned with centers of chalcocite-bornite, outer zones of chalcopyrite-pyrite, and peripheral galena-sphalerite. Some deposits contain carrollite and Co-pyrite commonly in the chalcopyrite-pyrite zone, and Ge minerals in the chalcocite-bornite zone.

Carbon-rich materials (bitumens, graphite, coal), although they are important components of favorable host rocks, are rarely found in copper ores. They are consumed by the redox reactions responsible for ore deposition.

Copper minerals can be arranged according to decreasing oxidation state as follows:

Mineral

Chalcopyrite

Covellite

Bornite

Anilite

Digenite

Djurleite

Chalcocite

Native Copper
Formula

$\mathrm{Cu} \mathrm{Fe} \mathrm{S}$

$\mathrm{Cu} \mathrm{S}$

$\mathrm{Cu}_{5} \mathrm{Fe} \mathrm{S}_{4}$

$\mathrm{Cu}_{7} \mathrm{~S}_{4}$

$\mathrm{Cu}_{9} \mathrm{~S}_{5}$

$\mathrm{Cu}_{31} \mathrm{~S}_{16}$

$\mathrm{Cu}_{2} \mathrm{~S}$

$\mathrm{Cu}$

\section{Oxidation state}

$$
\begin{aligned}
& \text { all } \mathrm{Cu}^{++} \\
& \text {all } \mathrm{Cu}^{++} \\
& \mathrm{Cu}^{++}: \mathrm{Cu}^{+}=1: 2 \\
& \mathrm{Cu}^{++}: \mathrm{Cu}^{+}=1: 3 \\
& \mathrm{Cu}^{++}: \mathrm{Cu}^{+}=1: 4 \\
& \mathrm{Cu}^{++}: \mathrm{Cu}^{+}=1: 15 \\
& \text { all } \mathrm{Cu}^{+} \\
& \text {all } \mathrm{Cu}^{0}
\end{aligned}
$$

Table 4 Copper minerals arranged by copper oxidation state

These minerals commonly form in zones with chalcocite deposited closest to the interface between brine and reduced fluid (Ripley and others, 1985). Covellite occurs in the transition zone between oxidized and reduced sediments. Pyrite occurs outside of the chalcopyrite zone. Cobalt, common in the African Copperbelt, is most abundant in the chalcopyrite zone, and galena and sphalerite in the Kupferschiefer of Poland mainly occur with pyrite (Oszczepalski, 1999).

The presence of cobalt, silver, lead and zinc in some deposits and not in others suggests that sedimentary exhalative processes may be important (Brown, 1984). High temperature deep basinal fluids introduced through basin-margin faults may overprint or mix with copper-rich brines to produce copper deposits with valuable byproducts.

Table 5 describes the occurrence of the most common minerals in each of the three deposit subtypes. Chalcocite is the most abundant mineral in 44 percent of the 
reduced facies occurrences described. Chalcopyrite is listed as most abundant in 17 percent of the occurrences.

\begin{tabular}{|l|c|l|c|c|c|c|}
\hline $\begin{array}{l}\text { Deposit } \\
\text { subtype }\end{array}$ & $\begin{array}{l}\text { Chalcocite, } \\
\text { digenite, } \\
\text { djurleite }\end{array}$ & Bornite & Chalcopyrite & Galena & Sphalerite & Pyrite \\
\hline $\begin{array}{l}\text { Reduced } \\
\text { facies }\end{array}$ & 82 & 61 & 72 & 8 & 6 & 30 \\
\hline Redbed & 58 & 30 & 34 & 3 & 3 & 28 \\
\hline
\end{tabular}

Table 5. Minerals present in individual occurrences by type expressed in percent of occurrences having a mineralogy description (57 reduced facies, 71 redbed).

Texture/Structure Finely disseminated, strata-bound, locally stratiform sulfides.

Framboidal or colloform pyrite is commonly replaced by copper sulfides. $\mathrm{Cu}_{2} \mathrm{~S}-\mathrm{CuS}$ minerals replace bornite which replaces chalcopyrite which replaces pyrite. Sulfides cluster around fossils, carbonaceous clots or fragments. Quartz in some ores contains fluid inclusions with $\mathrm{NaCl}, \mathrm{KCl}$, and rarely $\mathrm{BaCl}_{2}$ daughter minerals.

Alteration Dolomitization is common in carbonate host-rocks. Regionally metamorphosed red beds are purple in color and contain $\mathrm{Mg}$ chlorite derived from basinal brines. Red sediments are bleached to greenish gray or light gray where they have been in contact with reduced fluids. In Zambia host shale and siltstone contain 5 to 10 percent $\mathrm{K}_{2} \mathrm{O}$ and variable $\mathrm{MgO}$ up to 10 percent. These anomalous compositions are believed to result from diagenetic introduction of K-feldspar and chlorite (Moine and others, 1986)

Ore Controls Reducing environment such as pyritic black shales, algal mats or reef colonies are important ore controls. Sources of biogenic sulfide are also important. High permeability of footwall sediments is critical. The lowermost beds of transgressive reduced sediments, in contact with redbeds, are the most common loci of mineralization. In some deposits copper minerals are concentrated in sandstone beds that directly underlie the reduced-facies sediments (Oszczepalski and Rydzewsky, 1991). Rarely, as at Kennecott, Alaska, sulfides are hosted by fissures or karst breccias in organic rich carbonate rocks (MacKevett and others, 1997). Most important is the late orogenic development of fracture-permeability and hydrologic head to drive the process of fluid mixing. 
Weathering Malachite and azurite are common in outcrops, but in some permeable rocks, surface exposures may be completely leached. Secondary chalcocite enrichment down dip is present in some deposits but is uncommon because of low pyrite content and low acid production during weathering.

Geochemical Signature $\mathrm{Cu}, \mathrm{Ag}, \mathrm{Pb}, \mathrm{Zn}(\mathrm{Mo}, \mathrm{Re}, \mathrm{V}, \mathrm{U})(\mathrm{Co}, \mathrm{Ge})$. Au is low. Weak radioactivity is noted in some deposits. In the African Copperbelt treeless areas called "copper clearings," in which soil is copper-rich, occur over deposits (Hawkes and Webb, 1962; Reilly, 1967). These areas may contain copper-tolerant and copper-accumulating plants called "copper flowers" (Maisse and others, 1978; Reilly, 1967). Yellow leaf color (chlorosis), even among copper accumulating plants, is also common in copper clearings,

\section{EXAMPLES}

Kupferschiefer, PLND

Zambia deposits

Kamoto, ZIRE

Redstone, CNNT

Dongchuan, CINA
(Oszczepalski, 1999)

(Annels, 1989)

(Bartholome and others, 1976)

(Chartrand and others, 1989)

(Ruan and others, 1991)

\section{REFERENCES}

Annels, A.E., 1989, Ore genesis in the Zambian Copperbelt with particular reference to the northern sector of the Chambishi Basin, in Boyle, R.W., Brown, A.C., Jefferson, C.W., Jowett, E.C., and Kirkham, R.V. eds., Sediment-hosted Stratiform Copper Deposits: Geological Association of Canada Special Paper 36. p. 427-452.

Bolodin, R.N., Chechetkin, V.S., Bogdanov, Yu.V., Narkelyun, L.F., and Trubachev, A.I., 1994, The Udokan cupriferous sandstone deposits (Eastern Siberia): Geologiya Rudnykh Mestorozhdenii, Tom 36, p.3-30 (in Russian).

Brown, A.C., 1984, Alternative sources of metals for stratiform copper deposits: Precambrian Research, v. 25, p. 61-74.

Brown, A.C., and Chartrand, F.M., 1986, Diagenetic features at White Pine (Michigan), Redstone (N.W, Territories, Canada) and Kamoto (Zaire). Sequence of mineralization in sediment-hosted copper deposits (Part 1) in Friedrich, G.H., Genkin, A.D., Naldrett, A.J., Ridge, J.D., Sillitoe, R.H., and Vokes, F.M. Geology and Metallogeny 
of Copper Deposits, Proceedings $27^{\text {th }}$ International Geological Congress, Moscow, 1984: Berlin, Springer-Verlag, p. 390-397

Bartholomé, P., Evrard, P., Katekesha, F., Lopez-Ruiz, J. and Ngongo, M. 1976, Diagenetic ore-forming processes at Kamoto, Katanga, Republic of Congo, in Amstutz G. C., and Barnard, A. J., eds., Ores in sediments: New York, SpringerVerlag, p. 21-42.

Chartrand, F.M., Brown, A.C., and Kirkham, R.V., 1989, Diagenesis, sulphides, and metal zoning in the Redstone copper deposit, Northwest Territories, in Boyle, R.W., Brown, A.C., Jefferson, C.W., Jowett, E.C., and Kirkham, R.V. eds., Sediment-hosted Stratiform Copper Deposits: Geological Association of Canada Special Paper 36. p. 189-206

Cox, D.P., 1986, Descriptive model of sediment-hosted copper in Cox, D.P., and Singer, D. A., eds., Mineral deposit models: U.S. Geological Survey Bulletin 1693, 379 p Fleischer, V.D., Garlick, W.D., and Haldane, R., 1976, Geology of the Zambian Copperbelt in Wolf, K.H., ed., Handbook of Strata-bound and Stratiform Ore Deposits, v. 6, Chapter 6, p.223-352.

Garlick, 1989, Genetic interpretation from ore relations to algal reefs in Zambia and Zaire in Boyle, R.W., Brown, A.C., Jefferson, C.W., Jowett, E.C., and Kirkham, R.V. eds., Sediment-hosted Stratiform Copper Deposits: Geological Association of Canada Special Paper 36. p. 471-498.

Gustafson, L.B., and Williams, Neil, 1981, Sediment-hosted stratiform deposits of copper, lead and zinc, in Skinner, B.J., ed., Economic Geology Seventy-fifth Anniversary Volume: Economic Geology Publishing Company, p.39-178.

Hawkes, H.E., and Webb, J.S., 1962, Geochemistry in Mineral Exploration: New York, Harper and Row, 415 p.

Haynes, D.W., 1986a, Stratiform copper deposits hosted by low-energy sediments: I.

Timing of sulfide precipitation - an hypothesis: Economic Geology, v.81, p. 250-265. Haynes, D.W., 1986b, Stratiform copper deposits hosted by low-energy sediments: II. Nature of source rocks and composition of metal-transporting water: Economic Geology, v.81, p. 266-295. 
Kirkham, R.V, Carriere, J.J., Laramee, R.M., and Garson, D.F., 1994, Global distribution of sediment-hosted stratiform copper deposits and occurrences: Geological Survey of Canada Open File 2915b, 256 p.

Kirkham, R.V., 1989, Distribution, settings, and genesis of sediment-hosted stratiform copper deposits in Boyle, R.W., Brown, A.C., Jefferson, C.W., Jowett, E.C., and Kirkham, R.V. eds., Sediment-hosted Stratiform Copper Deposits: Geological Association of Canada Special Paper 36. p. 3-38.

Lefebvre, J.J., 1989, Depositional environment of copper-cobalt mineralization in the Katangan sediments of southeast Shaba, Zaire in Boyle, R.W., Brown, A.C., Jefferson, C.W., Jowett, E.C., and Kirkham, R.V. eds., Sediment-hosted Stratiform Copper Deposits: Geological Association of Canada Special Paper 36. p. 401-426. Lindsey, D.A., 1982, Copper shales, in Erickson, R.L., ed., Characteristics of mineral deposit occurrences: U.S. Geological Survey Open-File Report 82-795, p. 196-199.

Lur'ye, A.M., 1986, Formation conditions of copper-sandstone and copper-shale deposits, in, Friedrich, G.H., Genkin, A.D., Naldrett, A.J., Ridge, J.D., Sillitoe, R.H., and Vokes, F.M. eds., Geology and Metallogeny of Copper Deposits: Berlin, Heidelberg, Springer-Verlag, p.477-491

MacKevett, E.M., Jr., Cox, D.P., Potter R.W., II, and Silberman, M.L., 1997, Kennecotttype deposits, Wrangell Mountains, Alaska: High-grade copper deposition near a limestone-basalt contact in Goldfarb, R.J. and Miller, L.D., eds., Mineral deposits of Alaska: Economic Geology Monograph 9, p. 68-89.

Maisse, F., Gregoire, J., Brooks, R. R., Morrison, R. S., and Reeves, R. D., 1978, Aeolanthus biformifolius De Wild.: a hyperaccumulator of copper from Zaire: Science, v. 199 , no. 4331 , p. 887-888.

Moine, B., Guilloux, L., and Audeoud, D., 1086, Major element geochemistry of host rocks in some sediment-hosted copper deposits ) in Friedrich, G.H., Genkin, A.D., Naldrett, A.J., Ridge, J.D., Sillitoe, R.H., and Vokes, F.M. Geology and Metallogeny of Copper Deposits, Proceedings $27^{\text {th }}$ International Geological Congress, Moscow, 1984: Berlin, Springer-Verlag, p. 443-460.

Oszczepalski, S., 1999, Origin of the Kuferschiefer polymetallic mineralization in Poland: Mineralium Deposita, v. 34, p. 599-613 
Oszczepalski, S., 1989, Kupferschiefer in southwestern Poland: sedimentary environments, metal zoning, and ore controls, in Boyle, R.W., Brown, A.C., Jefferson, C.W., Jowett, E.C., and Kirkham, R.V. eds., Sediment-hosted Stratiform Copper Deposits: Geological Association of Canada Special Paper 36. p. 571-600.

Oszczepalski, S., and Rydzewsky, A., 1991, The Kupferschiefer mineralization in Poland: Zentralblatt fur Geologie und Paleontologie, Teil 1, v. 4, p.957-999.

Reilly, C., 1967, Accumulation of copper by some Zambian plants: Nature, v. 215, no. 5101, p. 667-668.

Ripley, Edward, Merino, Enrique, Moore, Craig, and Ortoleva, Peter, 1985, Mineral zoning in sediment-hosted copper deposits in Wolf, K.H., ed., Handbook of Stratabound and Stratiform Ore Deposits, v. 13, Chapter 3, p. 238-360

Rose, A.W., 1976. The effect of cuprous chloride complexes in the origin of red-bed copper and related deposits, Economic Geology, v.71, p. 1036-1048.

Ruan Huichu, Hua Renmin, and Cox, D.P., 1991, Copper deposition in deformed strata adjacent to a salt diapir, Dongchuan Area, Yunnan Province, China: Economic Geology v.86, p.1539-1545.

Ruffell, A.H., Moles, N.R. and Parnell, J., 1997, Characterization and prediction of sediment-hosted ore deposits using sequence stratigraphy: Ore Geology Reviews, V. 12, p. 207-223.

Sweeney, M.A. and Binda, P.L., 1989, The role of diagenesis in the formation of the Konkola $\mathrm{Cu}-\mathrm{Co}$ orebody of the Zambian Copperbelt in Boyle, R.W., Brown, A.C., Jefferson, C.W., Jowett, E.C., and Kirkham, R.V. eds., Sediment-hosted Stratiform Copper Deposits: Geological Association of Canada Special Paper 36. p. 499-518.

Sweeney, M.A. and Binda, P.L., and Vaughan, D.J., 1991, Genesis of ores of the Zambian Copperbelt: Ore Geology Reviews, V. 6, p. 51-7 
Model 30b.2

GRADE AND TONNAGE MODEL OF REDUCED FACIES Cu

By Dennis P. Cox and Donald A. Singer

(Replaces Model 30b of Mosier and others (1986)

COMMENTS: A deposit is defined as one or more separate orebodies separated from its nearest neighbor by more than $2,000 \mathrm{~m}$. The copper grade distribution is significantly different from lognormal because of the inclusion of two low-grade deposits from Nova Scotia, Canada, and Michigan, USA.

\section{DEPOSITS}

$\begin{array}{llll}\text { Name } & \text { Country } & \text { Name } & \text { Country } \\ \text { Boleo } & \text { MXCO } & \text { Lochaber Lake } & \text { CNNS } \\ \text { Bwana Mkubwa } & \text { ZMBA } & \text { Luanshya } & \text { ZMBA } \\ \text { Cachoeiras de Binga } & \text { ANGL } & \text { Lubin } & \text { PLND } \\ \text { Chambishi } & \text { ZMBA } & \text { Luishia } & \text { ZIRE } \\ \text { Chibuluma South } & \text { ZMBA } & \text { Lukuni } & \text { ZIRE } \\ \text { Chibuluma-Chibuluma West } & \text { ZMBA } & \text { Lupato } & \text { ZIRE } \\ \text { Chingola } & \text { ZMBA } & \text { Mangum } & \text { USOK } \\ \text { Coates Lake } & \text { CNNT } & \text { Mansfeld } & \text { GRMY } \\ \text { Creta } & \text { USOK } & \text { Mimbula } & \text { ZMBA } \\ \text { Etoile } & \text { ZIRE } & \text { Mindola-Nkana N-S ZMBA } \\ \text { FengShan } & \text { CINA } & \text { Mokambo } & \text { ZMBA } \\ \text { Fitula } & \text { ZMBA } & \text { Mount Gunson } & \text { AUSA } \\ \text { Fungurume } & \text { ZIRE } & \text { Mufulira } & \text { ZMBA } \\ \text { Jay } & \text { CNNT } & \text { Mutoshi } & \text { ZIRE } \\ \text { Juaramento } & \text { AGTN } & \text { Nchanga } & \text { ZMBA } \\ \text { June Creek } & \text { CNNT } & \text { Oamites } & \text { NAMB } \\ \text { Kabolela } & \text { ZIRE } & \text { Presque Isle } & \text { USMI } \\ \text { Kakanda } & \text { ZIRE } & \text { Richelsdorf } & \text { GRMY } \\ \text { Kamatanda } & \text { ZIRE } & \text { Sesa } & \text { ZIRE } \\ \text { Kambove } & \text { ZIRE } & \text { ShiShan } & \text { CINA } \\ \text { Kamfundwa } & \text { ZIRE } & \text { ShiZhiShan } & \text { CINA } \\ \text { Kimbwe } & \text { ZIRE } & \text { Talat } n \text { Ouamane } & \text { MRCO } \\ \text { Kinsenda } & \text { ZIRE } & \text { TangDan } & \text { CINA } \\ \text { Klein Aub } & \text { NAMB } & \text { Tenke } & \text { ZIRE } \\ \text { Kolwezi } & \text { ZIRE } & \text { Udokan } & \text { RUSA } \\ \text { Konkola-Kirila Bombwe } & \text { ZMBA } & \text { White Pine } & \text { USMI } \\ \text { Kona Dolomite } & \text { USMI } & \text { Witvlei } & \text { NAMB } \\ \text { Konrad } & \text { PLND } & \text { YinMin } & \text { CINA } \\ \text { LaoXue } & \text { CINA } & & \\ & \text { ZIN } & & \end{array}$




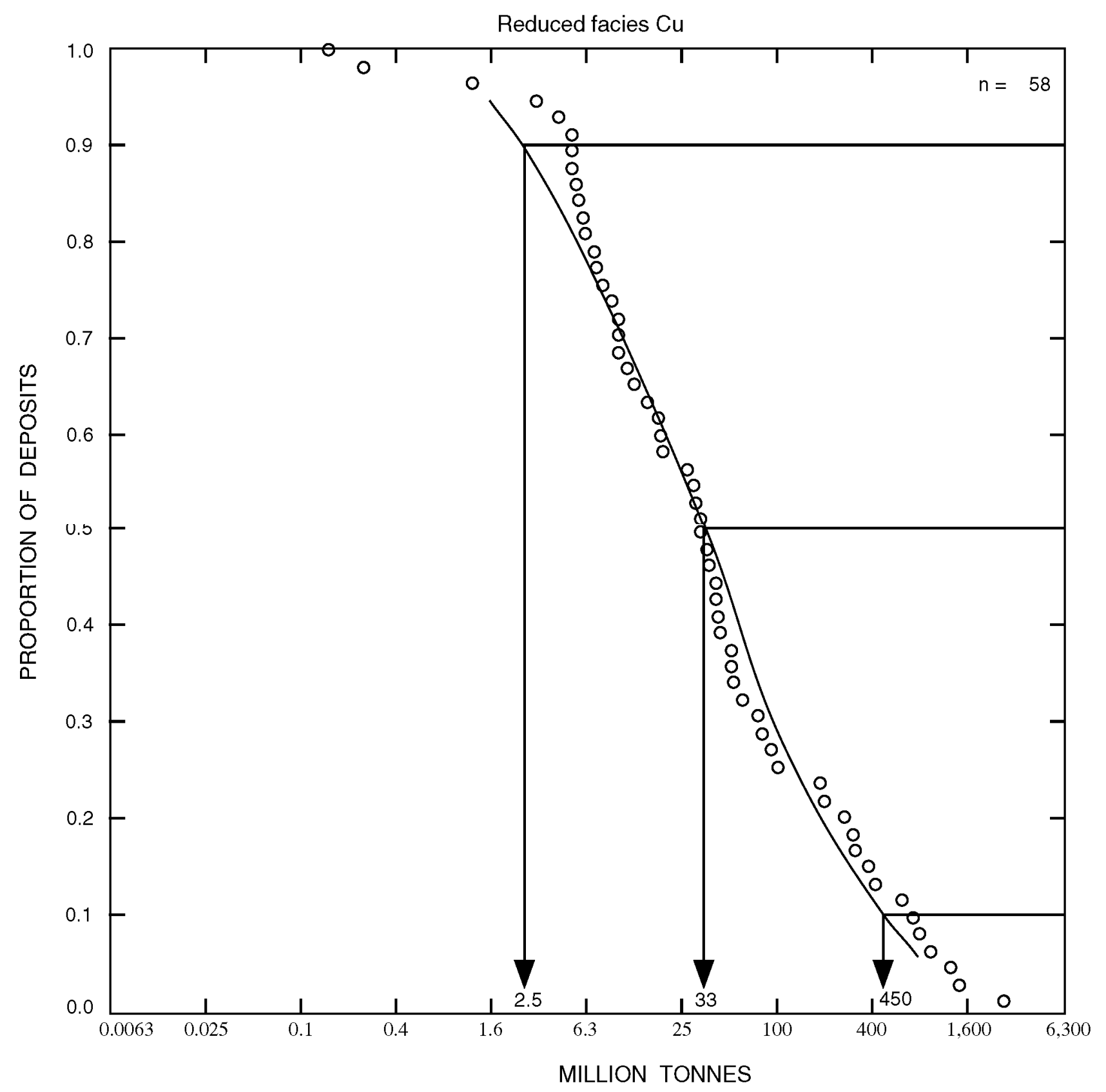

Figure 1. Tonnages of reduced facies $\mathrm{Cu}$ deposits. 
Reduced facies $\mathrm{Cu}$

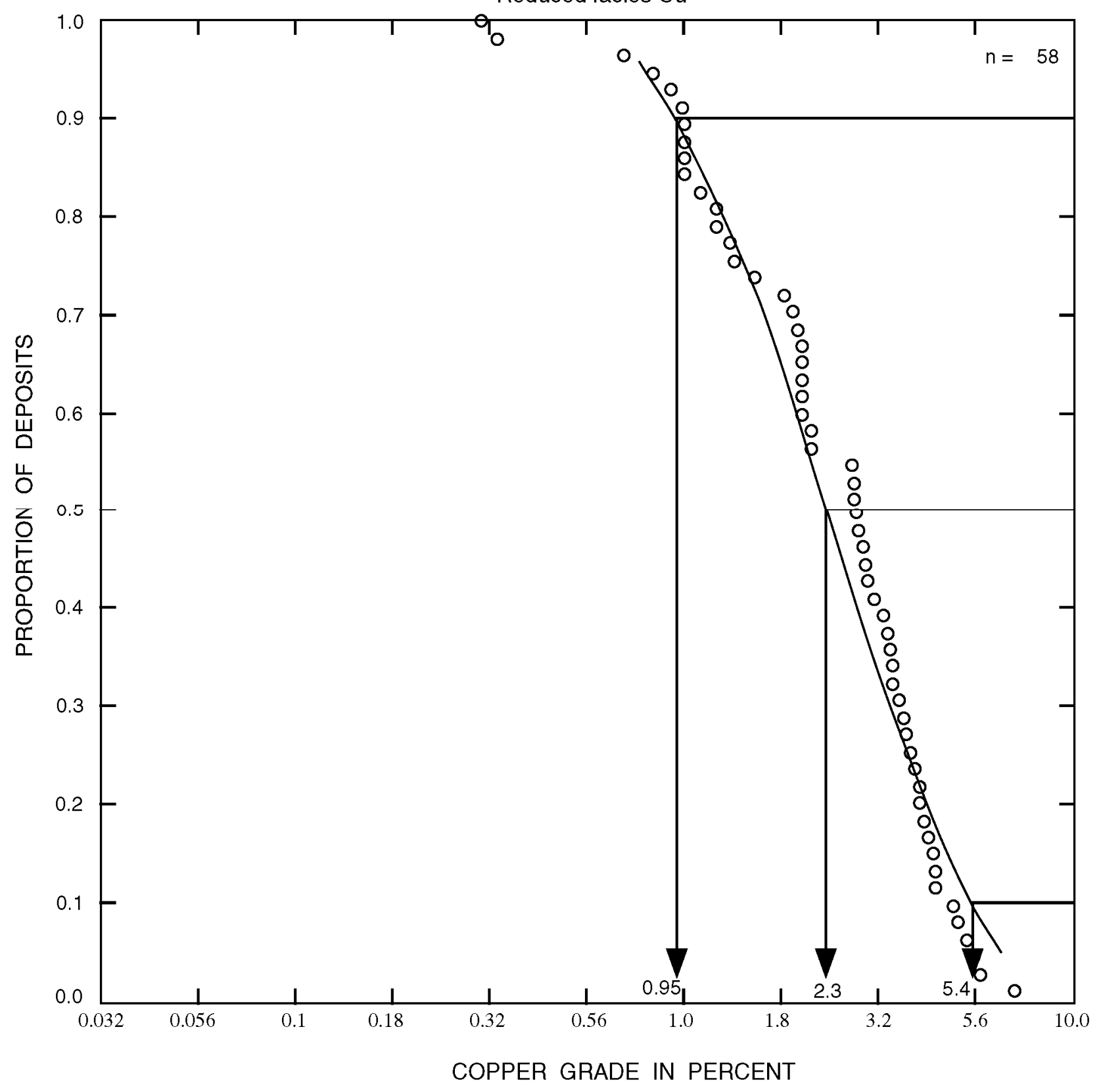

Figure 2. Copper grades of reduced facies $\mathrm{Cu}$ deposits. 
Reduced facies $\mathrm{Cu}$

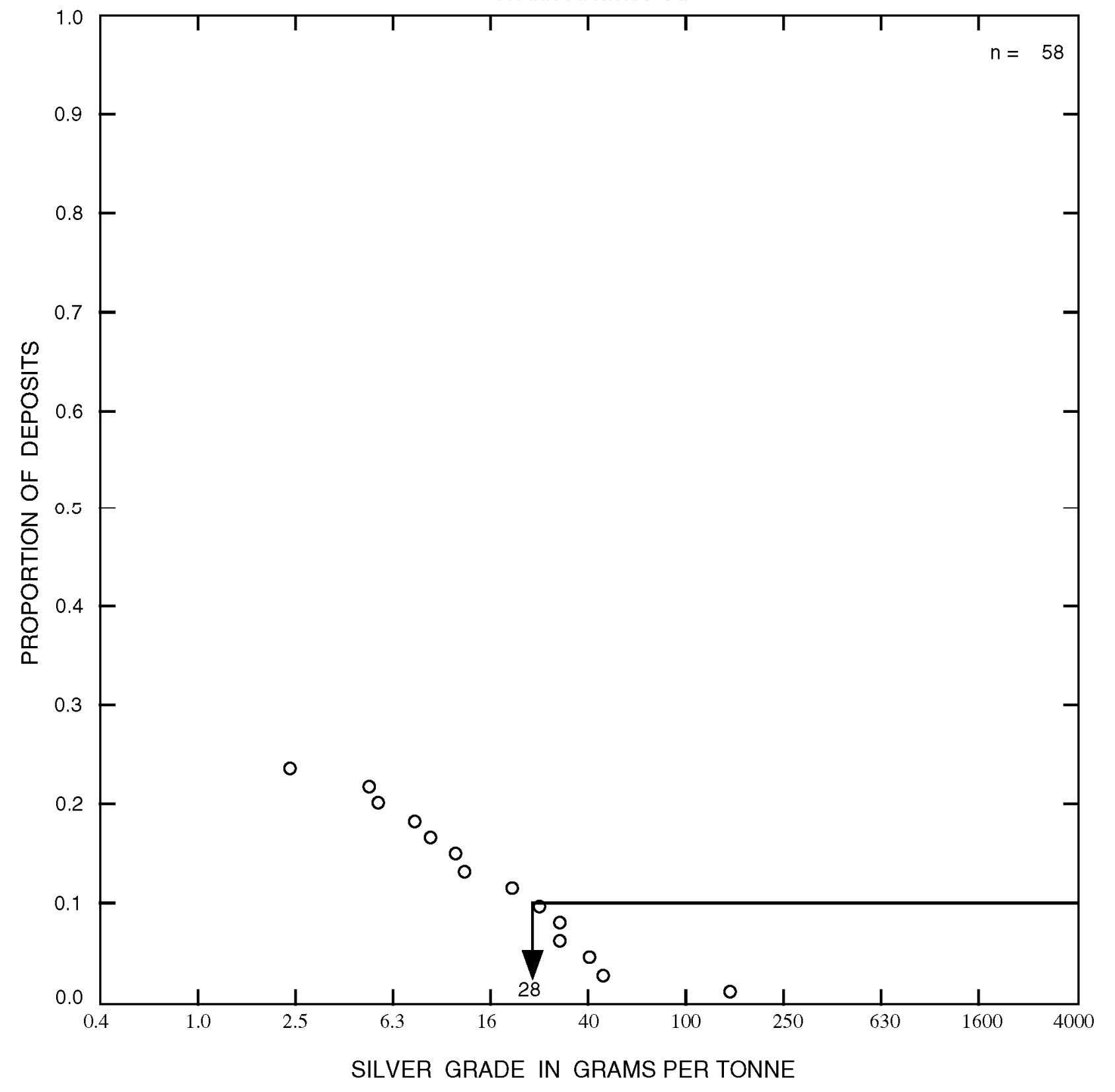

Figure 3. Silver grades of reduced facies $\mathrm{Cu}$ deposits. 


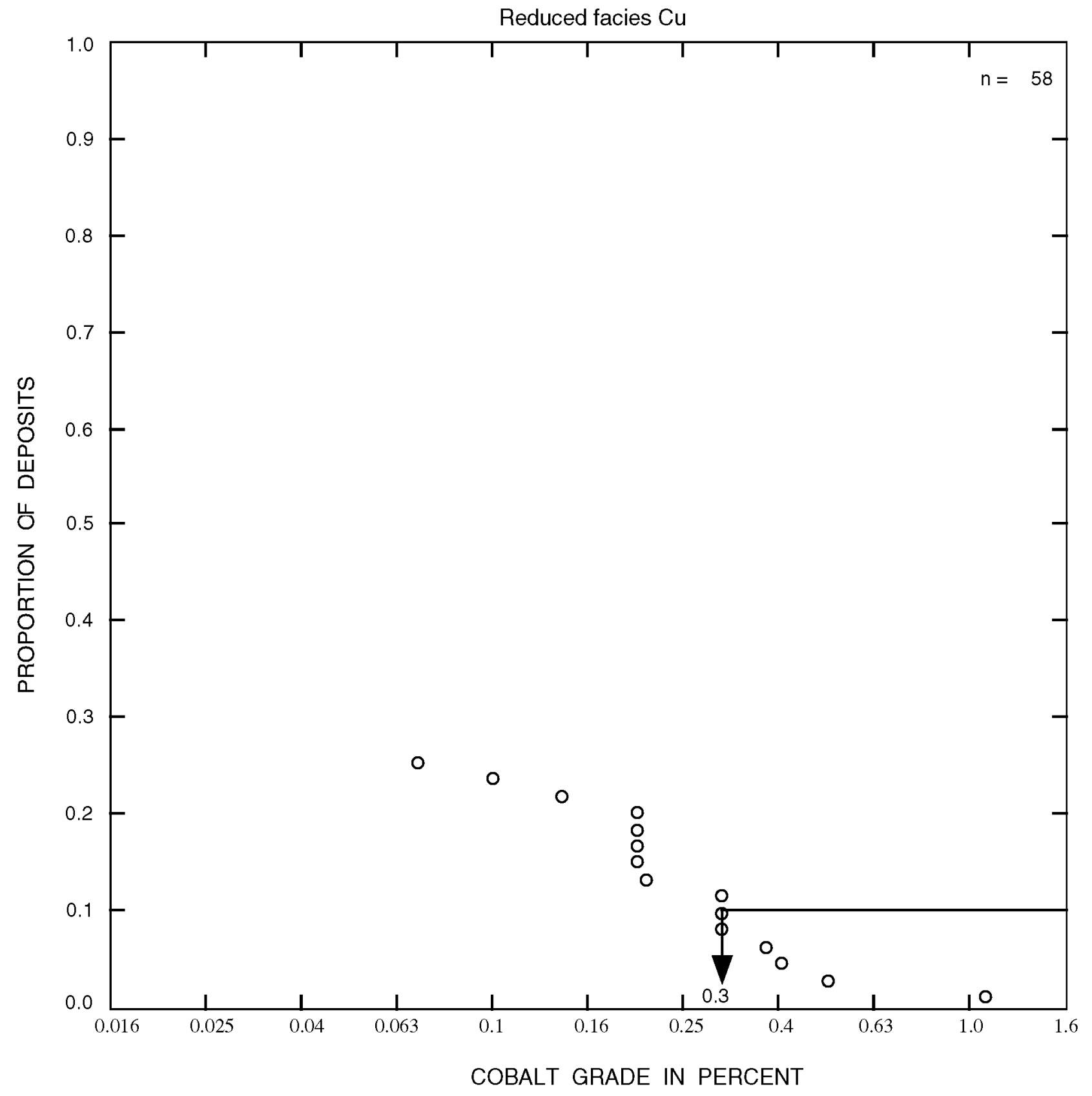

Figure 4. Cobalt grades of reduced facies $\mathrm{Cu}$ deposits. 
DESCRIPTIVE MODEL OF REDBED CU 30b.3, (Replaces Sediment-hosted Copper, 30b, Cox, 1986)

By David A. Lindsey and Dennis P. Cox

APPROXIMATE SYNONYMS Redbed-hosted $\mathrm{Cu}$, sandstone-hosted $\mathrm{Cu}$, Continental redbed (Kirkham and others, 1994)

DESCRIPTION Redbed copper deposits are stratabound mineralized bodies of disseminated copper and copper sulfides, with or without silver, uranium and vanadium, occurring in reduced zones of red-bed sequences.

GENERAL REFERENCES Gustafson and Williams (1981), Eugster (1989), and Kirkham (1989).

\section{GEOLOGICAL ENVIRONMENT}

Rock Types The characteristic stratigraphic setting for redbed copper deposits is a redbed sequence containing white or gray bleached zones in sandstone and/or black, grey, or green (reduced) beds of shale and siltstone. In Devonian and younger rocks, host beds commonly contain fossil plant debris. Local evaporite beds are present in some cases, but not in others. Reducing traps formed by plant debris are of limited lateral extent; thus redbed copper deposits are generally small (Eugster, 1989).

According to the Sediment-Hosted Copper Database, 85 percent of Redbed deposits and occurrences are hosted by sandstone or conglomerate. Note the contrast with reduced facies $\mathrm{Cu}$ deposits mainly hosted in fine-grained, low energy clastic rocks and carbonates (table 1).

\begin{tabular}{|l|l|l|l|l|c|}
\hline Deposit Type & $\begin{array}{l}\text { Number of } \\
\text { deposits } \\
\text { and } \\
\text { occurrences }\end{array}$ & $\begin{array}{l}\text { Sandstone, } \\
\text { quartzite, } \\
\text { arkose, } \\
\text { conglomerate }\end{array}$ & $\begin{array}{l}\text { Siltstone, } \\
\text { shale, } \\
\text { clay } \\
\text { mudstone, }\end{array}$ & $\begin{array}{l}\text { Limestone, } \\
\text { dolomite, } \\
\text { marl }\end{array}$ & $\begin{array}{l}\text { Schist, phyllite, } \\
\text { amphibolite, } \\
\text { marble }\end{array}$ \\
\hline Redbed & 155 & 85 & 12 & 2.5 & $<1$ \\
\hline Reduced facies & 100 & 29 & 41 & 28 & 2 \\
\hline Revett & 31 & 77 & 22 & 0 & $<1$ \\
\hline Unclassified & 102 & 30 & 20 & 25 & 25 \\
\hline
\end{tabular}

Table 1. Host rocks of mineralization for individual occurrences by type expressed in percent of occurrences having a host rock description (100 reduced facies, 155 redbed, 31 Revett, and 102 unclassified).

Redbed deposits are most commonly underlain by sandstone and conglomerate beds (table 2) 


\begin{tabular}{|l|l|l|l|l|c|c|}
\hline $\begin{array}{l}\text { Deposit } \\
\text { subtype }\end{array}$ & $\begin{array}{l}\text { Sandstone, } \\
\text { quartzite, } \\
\text { arkose, }\end{array}$ & $\begin{array}{l}\text { Conglom- } \\
\text { erate }\end{array}$ & $\begin{array}{l}\text { Siltstone, } \\
\text { shale, clay } \\
\text { mudstone, }\end{array}$ & $\begin{array}{l}\text { Limestone, } \\
\text { dolomite, } \\
\text { marl }\end{array}$ & Evaporite & $\begin{array}{l}\text { Mafic } \\
\text { lava }\end{array}$ \\
\hline Redbed & 39 & 26 & 13 & 8 & & 13 \\
\hline $\begin{array}{l}\text { Reduced } \\
\text { facies }\end{array}$ & 49 & 12 & 11 & 15 & 8 & 4 \\
\hline
\end{tabular}

Table 2. Rocks underlying mineralization for individual occurrences by type expressed in percent of occurrences having a description of the underlying rock (47 reduced facies and 26 redbed).

Textures Conglomerate- and sandstone-filled channels contain scour-and-fill, crossbedding, parallel lamination, mud rip-up clasts, and ripple marks. Siltstone and mudstone overbank deposits contain ripple marks, mud cracks, rootlet casts, and paleocaliche horizons.

Age Range No Archean deposits are known. The $4 \mathrm{Mmt}$ of copper in Proterozoic deposits are in the footwall sandstones of the Copperbelt of Zambia. These deposits are in red sandstones that underlie the large reduced facies deposits and are termed the footwall ore bodies. Many deposits are known in Paleozoic, Mesozoic, and Cenozoic rocks (see figure below).

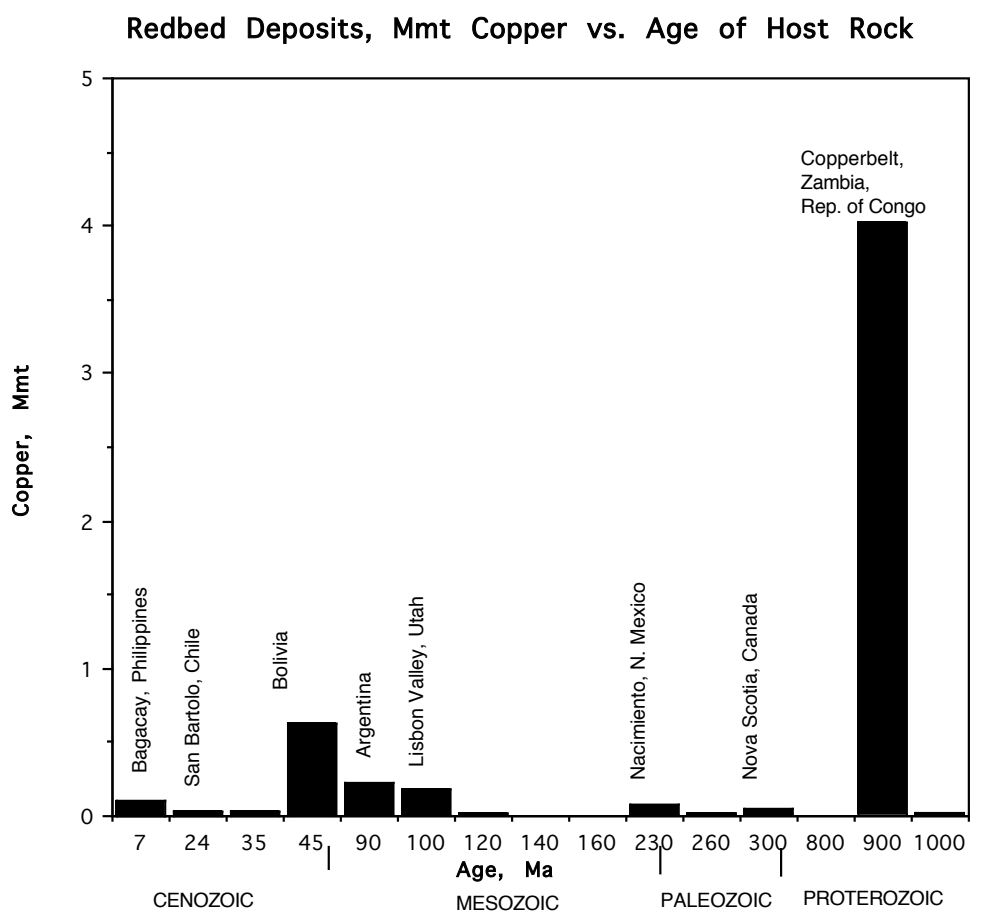

Depositional Environment Most host rocks were deposited within 30 degrees of the paleoequator (Kirkham, 1989). They were deposited by alluvial systems ranging from fans to meandering streams, commonly entering closed-basin playas or a variety of coastal environments, shallow epicontinental seas, and related evaporite basins. Sediments deposited in these 
environments are favorable hosts for oxidizing, saline fluids capable of leaching and transporting copper.

Tectonic Setting Redbed copper deposits occur in fault-bounded basins in various settings, including rifts, intermontane basins in broad zones of extension, and foreland molasse basins. Salt diapirism was important at Corocoro (Avila-Salinas, 1990; Cox and others, 1991).

Associated Deposit Types Sandstone (roll-front and tabular) uranium-vanadium, sandstone lead, reduced facies $\mathrm{Cu}$, and evaporites may all be associated at various scales.

\section{DEPOSIT DESCRIPTION}

Mineralogy Principal minerals are chalcocite and other $\mathrm{Cu}_{2} \mathrm{~S}$ minerals, pyrite, bornite, and native silver. Native copper is the dominant mineral in environments depleted in sulfur. Bitumins and oil residues may indicate the passage of fluid hydrocarbons. Copper sulfide replacement of early pyrite and carbonaceous plant debris is common in New Mexico deposits (Woodward and others, 1974). If present, uranium may also be concentrated in carbonaceous matter. Metal sulfide zoning ranges from grain to deposit scale, reflecting directions of fluid flow and/or chemical gradients. Typical zonation of $\mathrm{Cu}_{2} \mathrm{~S}$ minerals, bornite, chalcopyrite, pyrite, galena, and sphalerite reflects the relative solubility products of these sulfides. The stability of copper and iron sulfide minerals in this zonation can also be understood in the system $\mathrm{fO}_{2} / \mathrm{fS}_{2}$ at equilibrium, with sulfate (barite or gypsum) supplying sulfur for sulfide precipitation (Sverjensky, 1989). If redox sulfur disequilibrium occurs, fluids may react with organic matter to precipitate native copper. Deposit zoning is not evident in all examples.

According to the Sediment-Hosted Copper Database, chalcocite is listed as the most abundant mineral 58 percent of the time. Table 3

\begin{tabular}{|l|c|c|l|c|c|c|c|}
\hline $\begin{array}{l}\text { Deposit } \\
\text { subtype }\end{array}$ & $\begin{array}{l}\text { Chalcocite, } \\
\text { digenite, } \\
\text { djurleite }\end{array}$ & Bornite & $\begin{array}{l}\text { Chalco- } \\
\text { pyrite }\end{array}$ & Galena & Sphalerite & Pyrite & $\begin{array}{l}\text { Native } \\
\text { copper }\end{array}$ \\
\hline Redbed & 58 & 30 & 34 & 3 & 3 & 28 & 14 \\
\hline $\begin{array}{l}\text { Reduced } \\
\text { facies }\end{array}$ & 82 & 61 & 72 & 8 & 6 & 30 & 2 \\
\hline
\end{tabular}

Table 3. Minerals present in individual occurrences by type expressed in percent of occurrences having a mineralogy description (57 reduced facies, 71 redbed). Data from Cox and others (2003).

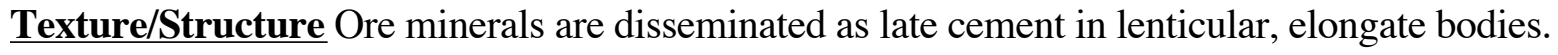
Mineralized replacement features may follow lamination and other sedimentary structures. Copper sulfides and native copper replace sandstone matrix, cement, and in some deposits, fossil plant 
debris and pyrite. Ore minerals embay and corrode detrital grains and gangue cement. Vein fillings that cross-cut earlier structures represent late-stage remobilization, after the main mineralizing event. Alteration Host beds are bleached white or gray; reduction spots and halos are common, especially around plant debris. Hematite and clay minerals are replaced by chlorite and ferroan calcite. Detrital and early diagenetic minerals are dissolved and replaced by ore minerals (Flint, 1989).

Ore Controls Permeable sandstone beds are major controls, as for example at the Nacimiento deposit in New Mexico (Woodward and others, 1974). Copper sulfides form locally around reductants such as plant debris and more broadly around concentrations of fluid hydrocarbons. Pyrite is a significant local reductant if abundant. Redox fronts (roll fronts) in ore-forming fluids and disequilibrium conditions are important chemical controls (Flint, 1989; Kirkham, 1989; Sverjensky, 1989).

Weathering Surface exposures of sulfides weather to hydroxides and carbonates, and may even be leached completely. Downdip and away from outcrop, supergene alteration and enrichment in chalcocite may occur.

Geochemical Signature $\mathrm{Cu}, \mathrm{Ag}, \mathrm{Pb}, \mathrm{Zn}$, (Mo, V, U). Some deposits weakly radioactive. Zambian redbed deposits contain Co.

\section{EXAMPLES}

Corocoro, BLVA

Nacimiento, USNM

Stauber, USNM
(Avila-Salinas, 1990; Flint, 1989)

(Woodward and others, 1974)

(Stauber, 1930)

\section{REFERENCES CITED}

Avila-Salinas, W., 1990, Origin of the copper ore at Corocoro, Bolivia in Fontbote, Amstutz, G. C., Cardozo, M., Cedillos, E., and Frutas, J., eds., Stratabound Ore Deposits of the Andes: BerlinHeidelberg, Springer Verlag, p. 659-670.

Cox, D.P., Carrasco, Raul, André-Ramos Orlando, Hinojosa-Velasco, Alberto, and Long, K.R., 1991, Copper deposits in sedimentary rocks in U.S. Geological Survey and Servicio Geológico de Bolivia, Geology and Mineral resources of the Altiplano and Cordillera Occidental, Bolivia with a section on Application of economic evaluations to deposit models by D.I. Bleiwas and R.G. Christiansen: U.S. Geological Survey Bulletin 1975, p.95-108.

Cox, D.P., Lindsey, D.A., Singer, D.A., and Diggles, M.F., 2003, Sediment-hosted copper deposits of the world: Deposit models and database: U.S. Geological Survey Open-File Report 03-107 (url: http://geopubs.wr.usgs.gov/open-file/of03-107/). 
Eugster, H. P., 1989, Geochemical environments of sediment-hosted $\mathrm{Cu}-\mathrm{Pb}-\mathrm{Zn}$ deposits in Boyle, R.W., Brown, A.C., Jefferson, C.W., Jowett, E.C., and Kirkham, R.V., Sediment-hosted stratiform copper deposits, Geological Association of Canada Special Paper 36, p. 111-126.

Flint, S. S., 1989, Sediment-hosted stratabound copper deposits of the Central Andes in Boyle, R.W., Brown, A.C., Jefferson, C.W., Jowett, E.C., and Kirkham, R.V., Sediment-hosted stratiform copper deposits, Geological Association of Canada Special Paper 36, p. 371-400..

Gustafson, L. B., and Williams, N., 1981, Sediment-hosted stratiform deposits of copper, lead and zinc in Skinner, B. J., ed., Economic Geology, 75th Anniversary Volume, p. 139-178.

Kirkham, R. V., 1989, Distribution, settings, and genesis of sediment-hosted stratiform copper deposits in Boyle, R.W., Brown, A.C., Jefferson, C.W., Jowett, E.C., and Kirkham, R.V., Sediment-hosted stratiform copper deposits, Geological Association of Canada Special Paper 36, p. 3-38.

Kirkham, R.V, Carriere, J.J., Laramee, R.M., and Garson, D.F., 1994, Global distribution of sediment-hosted stratiform copper deposits and occurrences: Geological Survey of Canada Open File 2915b, 256 p.

Sverjensky, D. A., 1989, Chemical evolution of basinal brines that formed sediment-hosted Cu-PbZn deposits in Boyle, R.W., Brown, A.C., Jefferson, C.W., Jowett, E.C., and Kirkham, R.V., Sediment-hosted stratiform copper deposits, Geological Association of Canada Special Paper 36, p. 127-134.

Stauber, I. J., 1930, A sandstone copper deposit: The Mining Journal, December, p. 929-931.

Talbott, L. W., 1974, Nacimiento pit, a Triassic strata-bound copper deposit in Ghost Ranch, New Mexico Geological Society Guidebook, 25th Field Conference, p. 301-303.

Woodward, L. A., Kaufman, W.H., Schumacher, O. L., and Talbott, L. W., 1974, Strata-bound copper deposits in Triassic sandstone of Sierra Nacimiento, New Mexico: Econ. Geology, v. 69, no. 1 , p. $108-120$. 
Model 30b.2

GRADE AND TONNAGE MODEL OF REDBED Cu

By Dennis P. Cox and Donald A. Singer

(Replaces Model 30b of Mosier and others (1986)

COMMENTS: A deposit is defined as one or more separate orebodies separated from its nearest neighbor by more than $2,000 \mathrm{~m}$.

\section{DEPOSITS}

$\begin{array}{llll}\text { Name } & \text { Country } & \text { Name } & \text { Country } \\ \text { Avaroa } & \text { BLVA } & \text { Mwerkera } & \text { ZMBA } \\ \text { Bagacay } & \text { PLPN } & \text { Nacimiento } & \text { USNM } \\ \text { Barda González } & \text { AGTN } & \text { Ngwako Pan } & \text { BOTS } \\ \text { Canfield Creek } & \text { CNDA } & \text { Nkana North Limb } & \text { ZMBA } \\ \text { Cerro Granito } & \text { AGTN } & \text { Pitanda } & \text { ZMBA } \\ \text { Chacarilla } & \text { BLVA } & \text { Pitanda South } & \text { ZMBA } \\ \text { Chifupu } & \text { ZMBA } & \text { Rubjerg Knude } & \text { GRLD } \\ \text { Corocoro } & \text { BLVA } & \text { San Bartolo } & \text { CILE } \\ \text { Dorchester } & \text { CNNS } & \text { San Romeleo } & \text { AGTN } \\ \text { Esmeralda } & \text { BLVA } & \text { Scholle } & \text { USMN } \\ \text { Itawa } & \text { ZMBA } & \text { Sevaruyo } & \text { BLVA } \\ \text { Jabal Murryyi } & \text { SAAR } & \text { Stauber } & \text { USNM } \\ \text { Kasaria } & \text { ZMBA } & \text { Tansrift } & \text { MRCO } \\ \text { Ladderbjerg } & \text { GRLD } & \text { Turco } & \text { BLVA } \\ \text { Luansobe } & \text { ZMBA } & \text { Uyuni } & \text { BLVA } \\ \text { Martín Bronce } & \text { AGTN } & \text { Wadi Yiba } & \text { SAAR } \\ \text { Mwambashi } & \text { ZMBA } & & \end{array}$




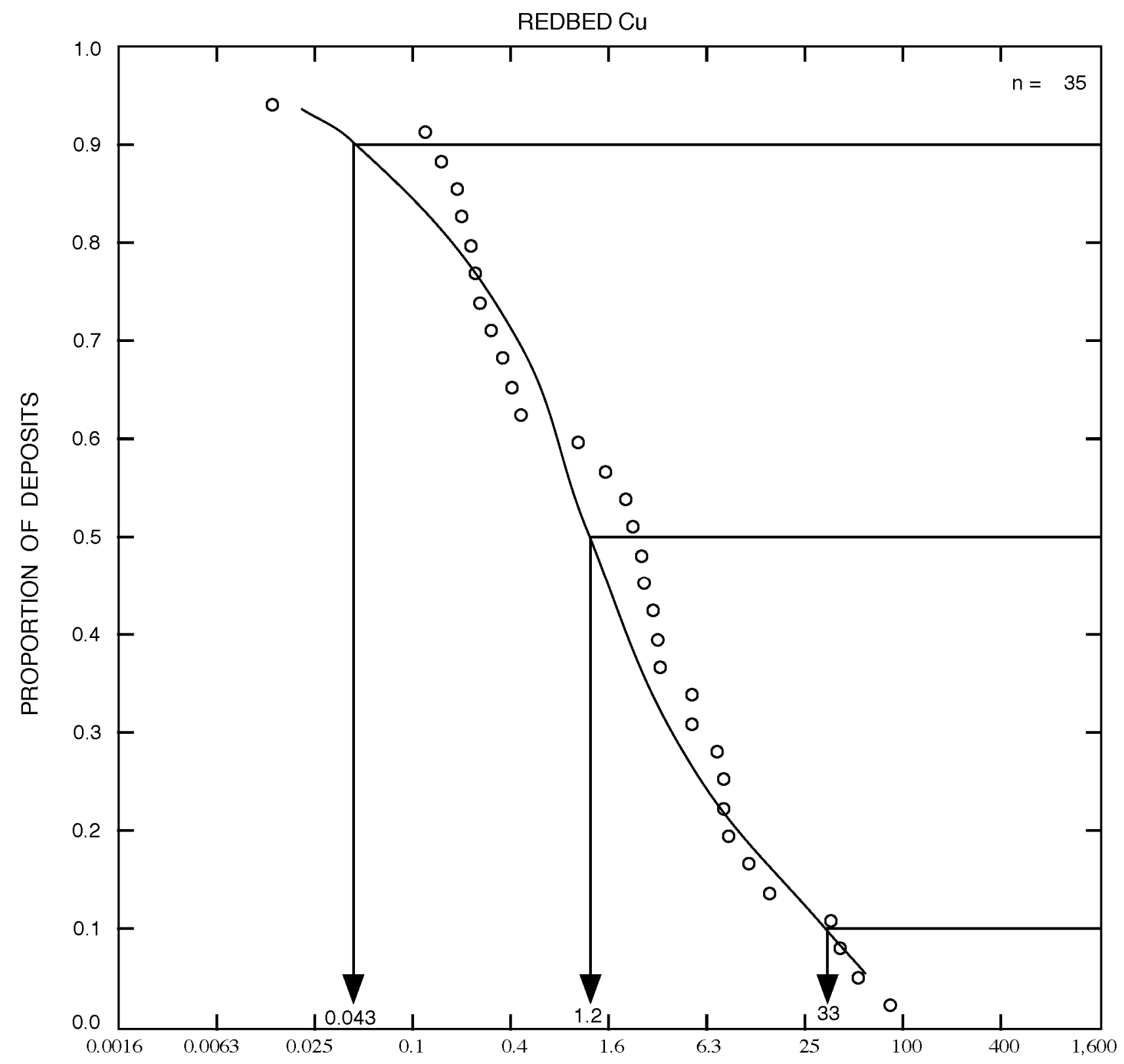

MILLION TONNES

Figure 1. Tonnages of redbed Cu deposits. 


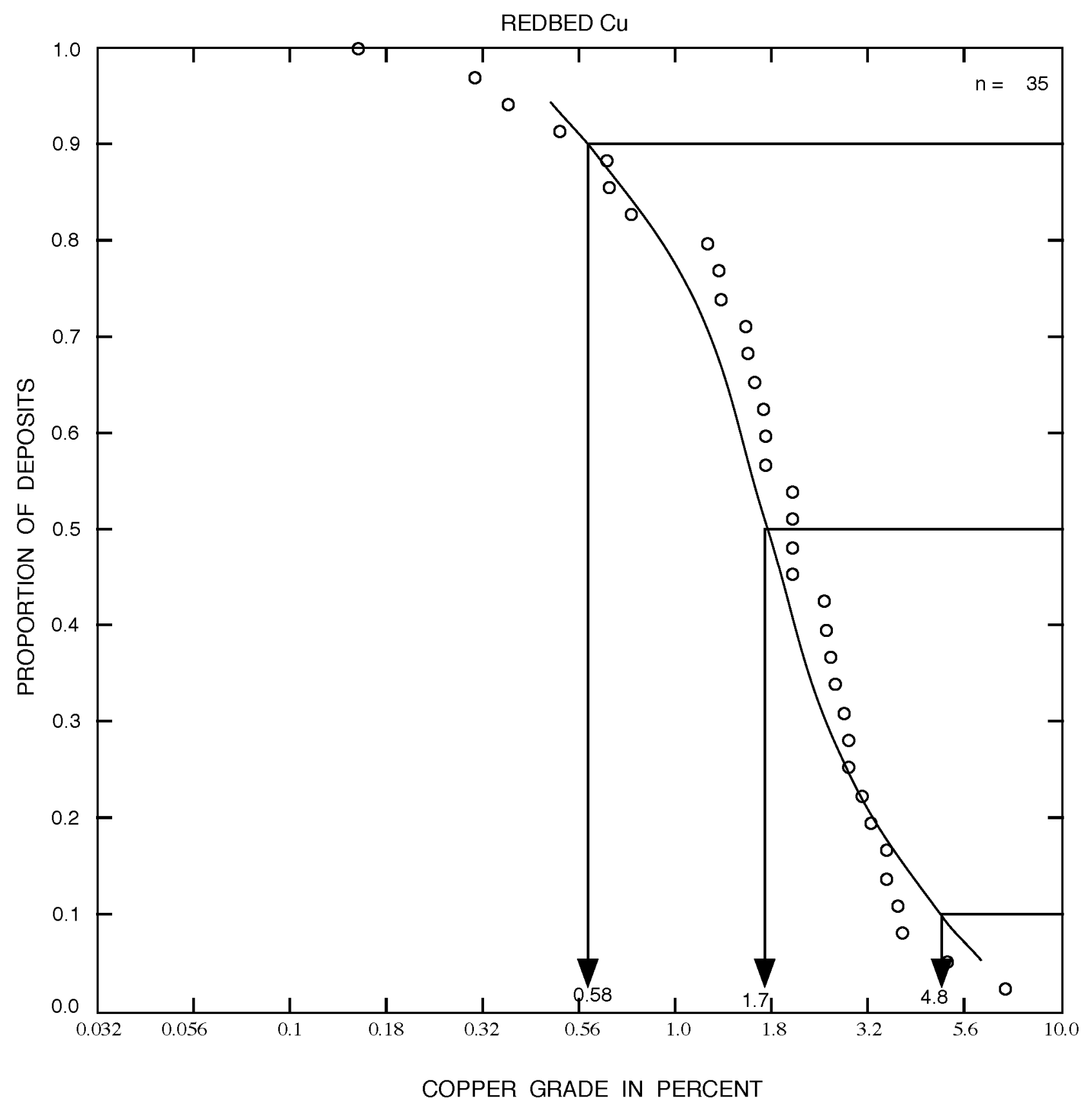

Figure 2. Copper grades of redbed Cu deposits. 


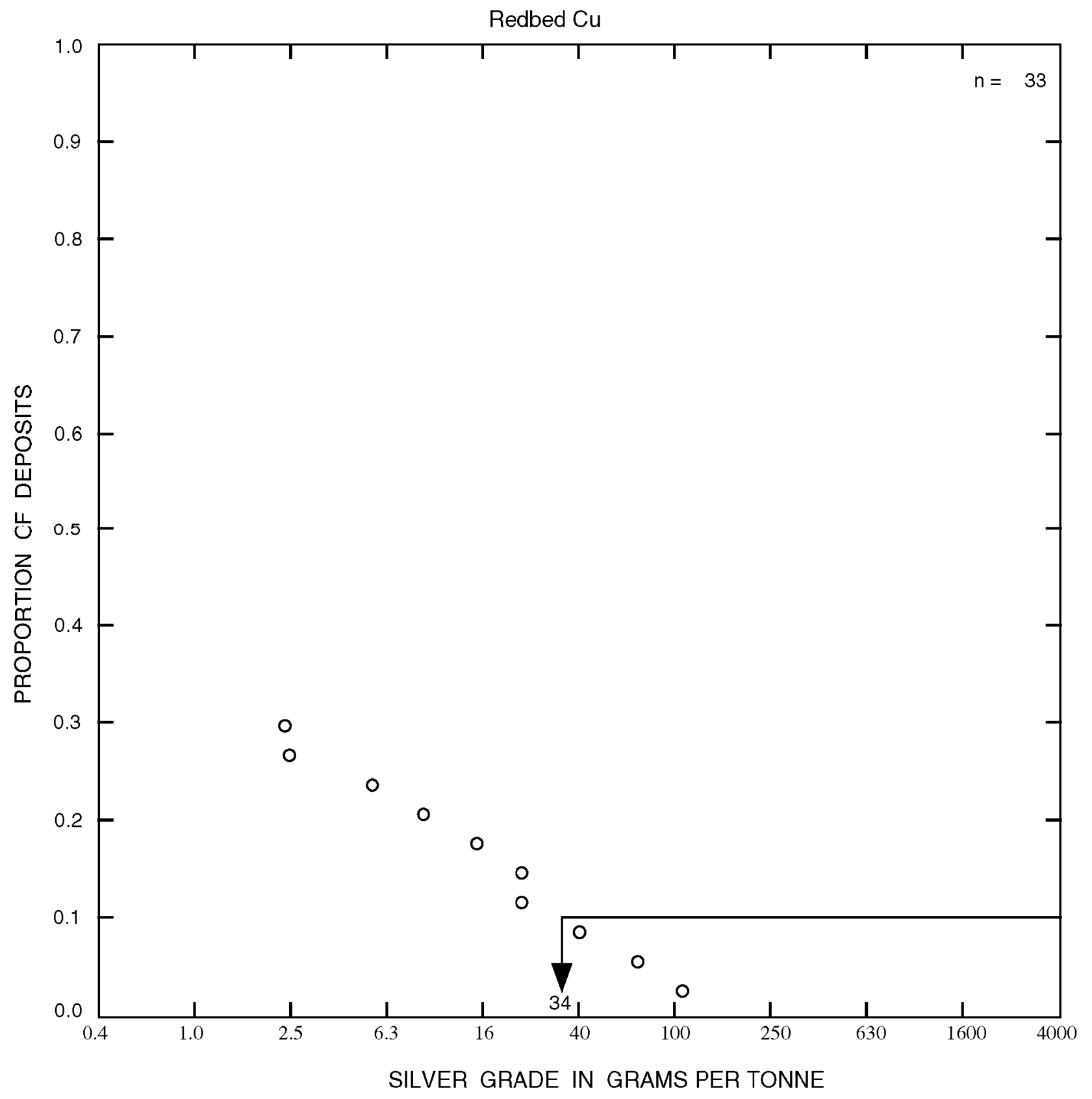

Figure 3. Silver grades of redbed Cu deposits. 
DESCRIPTIVE MODEL OF REVETT CU 30b.4, (Replaces Sediment-hosted Copper, 30b (Cox, 1986)

By Dennis P. Cox

\begin{abstract}
APPROXIMATE SYNONYMS None
DESCRIPTION Revett copper deposits are stratabound mineralized bodies of disseminated copper and lead-zinc sulfides with silver, occurring on broad redox boundaries associated with color changes in redbed sequences.
\end{abstract}

\title{
GENERAL REFERENCES None GEOLOGICAL ENVIRONMENT
}

Rock Types The characteristic stratigraphic setting for Revett copper deposits is a thick sandstone sequence. Sandstones are commonly red and contain white, gray or green alteration zones (Susura and others,1986). In Devonian and younger rocks, host beds commonly contain bitumins or other evidence for petroleum fluids. Evaporite beds are present in some cases. Deposits form as a result of mixing of copper-rich brines with ground water in equilibrium with pyrite (T.S. Hayes, oral commun. 2002) or with hydrocarbon fluids. The Dzhezkzagan deposit and other similar deposits and occurrences hosted by Carboniferous rocks are situated on the edge of the Chu Sari Su and Tengiz oil and gas fields. These fields have reservoir rocks of Carboniferous age (Popov, 1962). Gablina (1981) hypothesized that the Dzhezkzagan deposit was formed by mixing of brines with fluid hydrocarbons. Hayes and Einaudi (1986) postulated a reduced fluid as the reductant responsible for precipitation of the copper sulfides at Spar Lake Montana. Evidence for this fluid is the presence of pyrite and iron-rich calcite or ankerite in the sandstone (Hayes, 1990).

Among deposits in the Sediment-Hosted Copper Database (Cox and others, 2003), Revett deposits are most commonly hosted by sandstone, but 22 percent are contained in fine-grained clastic rocks (table 1). 


\begin{tabular}{|l|l|l|c|l|c|}
\hline Deposit Type & $\begin{array}{l}\text { Number of } \\
\text { deposits } \\
\text { and } \\
\text { occurrences }\end{array}$ & $\begin{array}{l}\text { Sandstone, } \\
\text { quartzite, } \\
\text { arkose, } \\
\text { conglomerate }\end{array}$ & $\begin{array}{l}\text { Siltstone, } \\
\text { shale, clay } \\
\text { mudstone, }\end{array}$ & $\begin{array}{l}\text { Limestone, } \\
\text { dolomite, } \\
\text { marl }\end{array}$ & $\begin{array}{l}\text { Schist, } \\
\text { phyllite, } \\
\text { amphibolite, } \\
\text { marble }\end{array}$ \\
\hline Revett & 31 & 77 & 22 & 0 & $<1$ \\
\hline Redbed & 155 & 85 & 12 & 2.5 & $<1$ \\
\hline $\begin{array}{l}\text { Reduced } \\
\text { facies }\end{array}$ & 100 & 29 & 41 & 28 & 2 \\
\hline Unclassified & 102 & 30 & 20 & 25 & 25 \\
\hline
\end{tabular}

Table 1. Host rocks of mineralization for individual occurrences by type expressed in percent of occurrences having a host rock description.

Textures Sandstones are well bedded and cross-laminated representing distal alluvial deposition and reworking in shallow marine or lacustrine basins. Localized stromatolitic layers as well as "sand pillows" or slump structures of sand into underlying silt beds are widespread (Garlick, 1988). "Ore rods" or mineralized fluid escape structures suggest that the underlying beds were the source of copper-rich solutions (Hayes and Einaudi, 1986).

At Dzhezkazgan, red and brown sandstones show cross-bedding and abundant erosional hiatuses with desiccation cracks and relict root systems. Broad lenses of green or gray sandstone in the redbeds are secondary and cross the bedding at low angles (Gablina, 1981).

Age Range No Archean deposits are known. Middle Proterozoic deposits are in the Belt Supergroup of Montana. The largest Revett deposit is Dzhezkazgan in the Lower Carboniferous of central Kazakstan.

Depositional Environment Most host rocks were deposited within 30 degrees of the paleoequator (Kirkham, 1989). They were deposited as fan deltas commonly entering closedbasin playas or a variety of coastal environments, shallow epicontinental seas, and related evaporite basins. Sediments deposited in these environments are favorable hosts for oxidizing, hematite stable, saline fluids capable of leaching and transporting copper. Nearby marine basins with oil and gas deposits are good guides to mineralization in redbeds as in Kazakstan (Gablina, 1981).

Tectonic Setting Revett copper deposits occur in fault-bounded basins in various settings, including rifts, intermontane basins in broad zones of extension, and foreland molasse basins. At 
Dzhezkazgan fluid mixing and ore deposition took place over a paleo uplift at the margin of the redbed basin (Gablina, 1981).

Associated Deposit Types Sandstone lead deposits resemble the fringing galena sphalerite zone of Revett deposits, but there is no record of an actual association of these two types.

\section{DEPOSIT DESCRIPTION}

Mineralogy Principal minerals are chalcocite and other $\mathrm{Cu}_{2} \mathrm{~S}$ minerals, chalcopyrite, bornite, and native silver. Bitumens and oil residues may indicate the passage of fluid hydrocarbons. Metal sulfide zoning ranges from grain to deposit scale, reflecting directions of fluid flow and/or chemical gradients. Zones of $\mathrm{Cu}_{2} \mathrm{~S}$ minerals, bornite, chalcopyrite, pyrite, galena, and sphalerite are arranged across redox boundaries with chalcocite on the oxidized side and pyrite and $\mathrm{Pb}-\mathrm{Zn}$ sulfides on the reduced side. Most common gangue minerals are quartz, iron-rich calcite, and aragonite.

Texture/Structure Ore minerals are disseminated as late cement in lenticular bodies. Mineralized replacement features may follow zones with highest prelithification permeability. Mineral zones also commonly follow roll fronts. Fluid escape structures are mineralized at Spar Lake and other deposits (Hayes and Einaudi, 1986).

Alteration. Where oxidized brines have passed through redbed sequences in the source-rock area of redbed deposits, lavender-gray, hematite and magnetite bearing, albite-rich, carbonatefree rocks depleted in K, Ca and most base metals are formed (Hayes, 1990).

Reduced fluids in redbeds produce pale gray or green rocks with disseminated pyrite, Fecalcite, ankerite and chlorite. This alteration is equivalent to that accompanying the distal chalcopyrite-pyrite and galena-bearing zones of the copper deposits (Hayes, 1990).

Ore Controls. Beds with high pre-ore permeability are the major ore controls. Redox fronts (roll fronts) in ore-forming fluids control copper deposition. At Spar Lake, fluid mixing responsible for ore deposition occurred as fluids move vertically through the section (Hayes, 1990). Syndepositional faulting acts as ore control in Montana deposits(Hayes and Einaudi, 1986). At Dzhezkazgan, reduced fluids moved laterally down the shallow dip of the beds (Gablina, 1981). Weathering Surface exposures of sulfides weather to hydroxides and carbonates, and may even be leached completely. 
Geochemical Signature $\mathrm{Cu}, \mathrm{Ag}, \mathrm{Pb}, \mathrm{Zn},(\mathrm{Mo}, \mathrm{V}, \mathrm{U})$. Some deposits weakly radioactive. Kazak deposits contain Mo and Re.

\section{EXAMPLES}

Spar Lake, USMN (Hayes and Einaudi, 1986)

Montanore-Rock Creek, USMT （Adkins, 1993)

Dzhezkazgan, USKZ (Gablina, 1981)

\section{REFERENCES CITED}

Adkins, A.R., 1993, Geology of the Montanore stratabound Cu-Ag deposit, Lincoln and Sanders Counties, Montana: Montana Bureau of Mines and Geology Open File Report 381, 3 p.

Cox, D.P., Lindsey, D.A., Singer, D.A., and Diggles, M.F., 2003, Sediment-hosted copper deposits of the world: Deposit models and database: U.S. Geological Survey Open-File Report 03-107 (url: http://geopubs.wr.usgs.gov/open-file/of03-107/).

Gablina, I.F., 1981, New data on formation conditions of the Dzhezkazgan copper deposit: International Geology Review, v. 23, p. 1303-1311.

Garlick, W.G., 1988, Algal mats, load structures, and synsedimentary sulfides in Revett Quartzite of Montana and Idaho: Economic geology, v.83, p. 1259-1278

Hayes, T.S., and Einaudi, M.T., 1986, Genesis of the Spar Lake strata-bound copper-silver deposit, Montana: Part 1. Controls inherited from sedimentation and preore diagenesis: Economic Geology, v. 81, p. 1899-1931.

Hayes, T.S., Rye, R.O., Whelan, J.F., and Landis, G.P.,1989, Geology and sulfur isotope geothermometry of the Spar Lake stratabound $\mathrm{Cu}-\mathrm{Ag}$ deposit in the Belt Supergroup, Montana in Boyle, R.W., Brown, A.C., Jefferson, C.W., Jowett, E.C., and Kirkham, R.V. eds., Sediment-hosted Stratiform Copper Deposits: Geological Association of Canada Special Paper 36, p. 319-338

Hayes, T.S, 1990, A preliminary study of thermometry and metal sources of the Spar Lake stratabound copper-silver deposit, Belt Supergroup, Montana: U.S. Geological Survey Open File Report 90-0484, 30 p.

Kirkham, R. V., 1989, Distribution, settings, and genesis of sediment-hosted stratiform copper deposits in Boyle, R.W., Brown, A.C., Jefferson, C.W., Jowett, E.C., and Kirkham, R.V., 
Sediment-hosted stratiform copper deposits, Geological Association of Canada Special Paper 36, p. 3-38.

Popov, V.M., 1962, Geologic regularities in the distribution of cupriferous sandstones in central Kazakhstan and the Northern Tyan'-Shan: International Geology Review, v. 4, p. 393-411. Susura, B.B., Glybovsky, V.O., and Kislitsin, A.V., 1986, Red-colored terrigenous sediments - specific copper-forming systems in Friedrich, G.H., Genkin, A.D., Naldrett, A.J., Ridge, J.D., Sillitoe, R.H., ., and Vokes, F.M. Geology and Metallogeny of Copper Deposits, Proceedings $27^{\text {th }}$ International Geological Congress, Moscow, 1984: Berlin, Springer-Verlag, p. 504-512. 
Model 30b.4

\author{
GRADE AND TONNAGE MODEL OF REVETT Cu \\ By Dennis P. Cox and Donald A. Singer \\ (Replaces Model 30b of Mosier and others (1986)
}

COMMENTS: A deposit is defined as one or more separate orebodies separated from its nearest neighbor by more than 2,000 m. Rock Creek deposit includes Montanore, Rock Lake, Copper Gulch, Horizon Basin, and Rock Peak. Copper grade is corelated with silver grade $(r=0.77, n=8)$ at the five-percent level.

\title{
DEPOSITS
}

$\begin{array}{llll}\text { Name } & \text { Country } & \text { Name } & \text { Country } \\ \text { Big Indian } & \text { USUT } & \text { Niagara } & \text { USID } \\ \text { Cashin } & \text { USCO } & \text { Rock Creek } & \text { USMT } \\ \text { Dzhezkazgan } & \text { KAZN } & \text { Snowstorm } & \text { USID } \\ \text { JF } & \text { USMT } & \text { Spar Lake } & \text { USMT } \\ \text { Lisbon Valley } & \text { USUT } & & \text { Vermillion River USMT } \\ \text { Missoula National } & \text { USID } & & \end{array}$




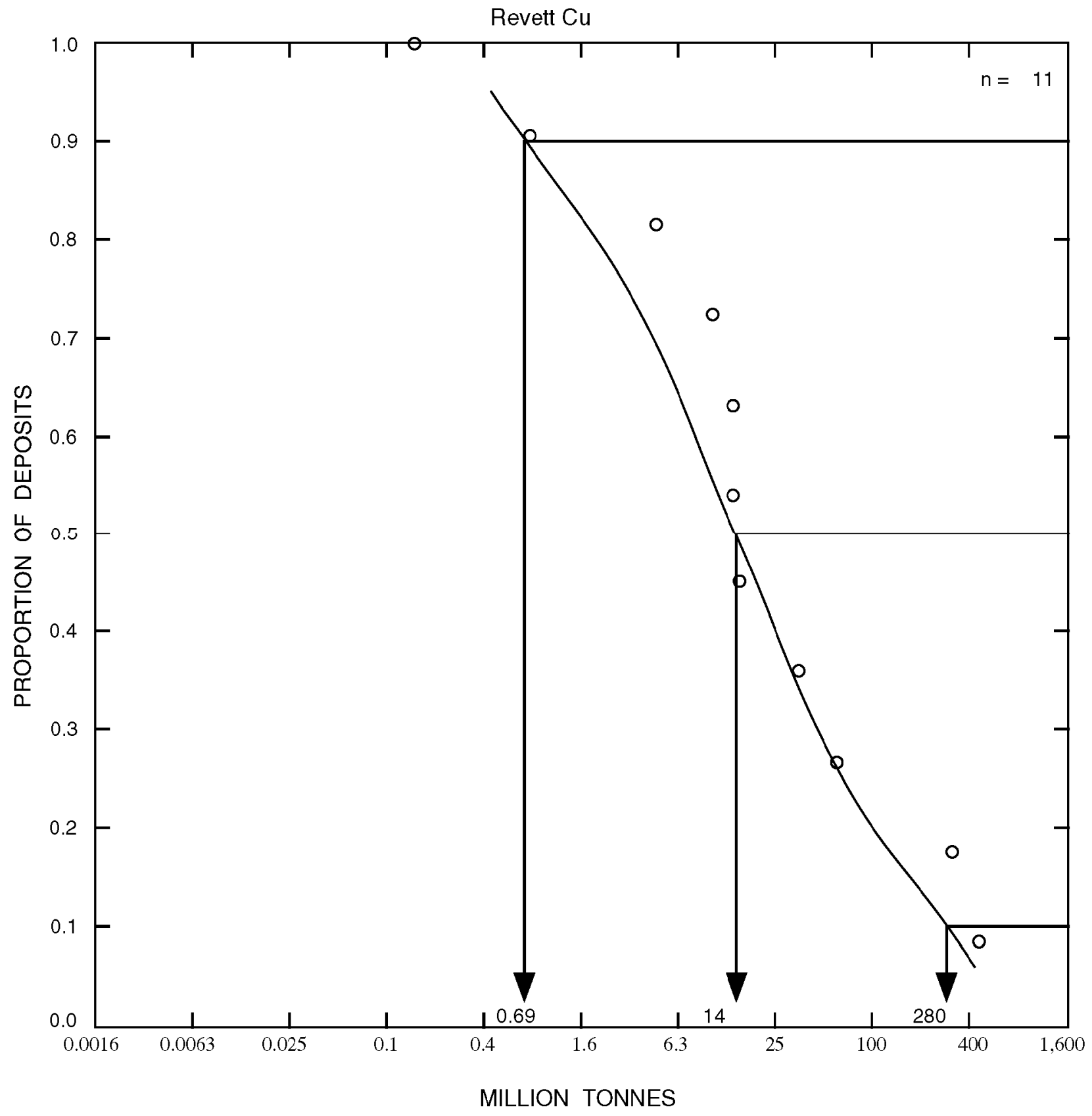

Figure 1. Tonnages of Revett Cu deposits. 


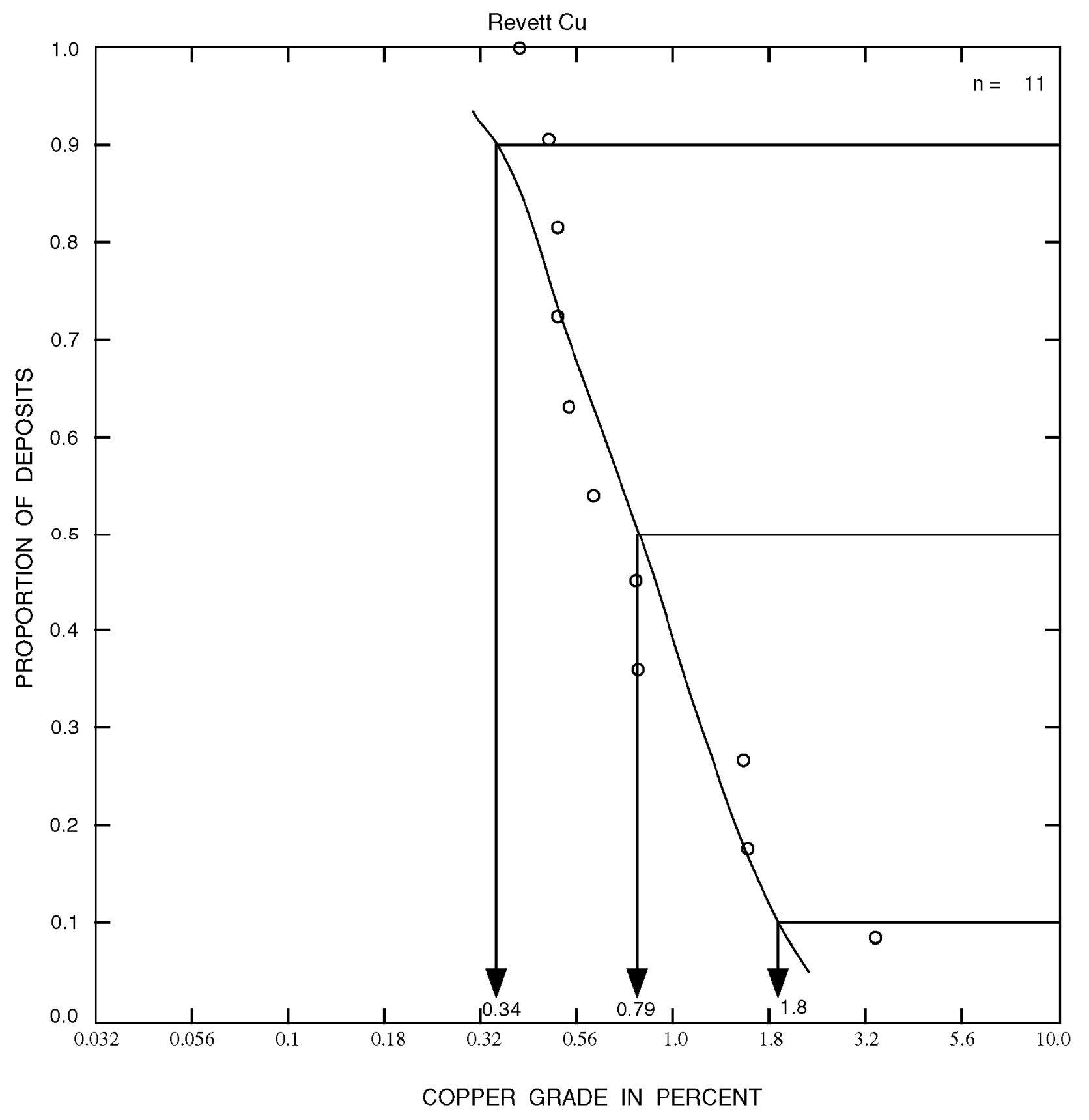

Figure 2. Copper grades of Revett Cu deposits. 


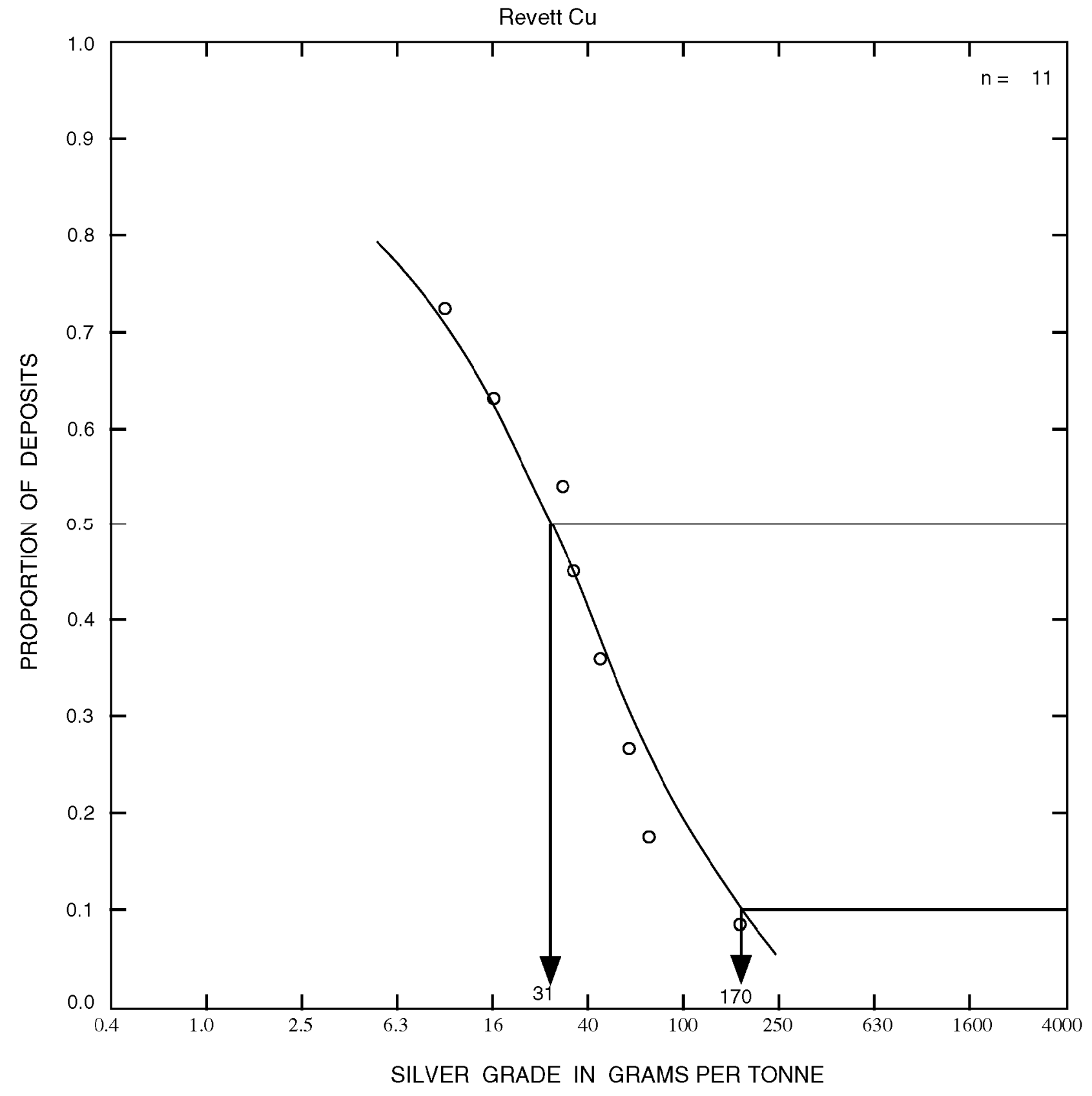

Figure 3. Silver grades of Revett Cu deposits. 